Cover. Streamgage on the Currituck Sound, North Carolina (photograph taken by W. Scott Caldwell, U.S. Geological Survey). 


\section{Simulation of Water Quality in the Tull Creek and West Neck Creek Watersheds, Currituck Sound Basin, North Carolina and Virginia}

By Ana María García

Prepared in cooperation with the North Carolina Department of Environment and Natural Resources, Division of Water Resources

Scientific Investigations Report 2008-5226 


\section{U.S. Department of the Interior DIRK KEMPTHORNE, Secretary}

\section{U.S. Geological Survey \\ Mark D. Myers, Director}

\section{U.S. Geological Survey, Reston, Virginia: 2009}

For product and ordering information:

World Wide Web: http://www.usgs.gov/pubprod

Telephone: 1-888-ASK-USGS

For more information on the USGS — the Federal source for science about the Earth, its natural and living resources, natural hazards, and the environment:

World Wide Web: http://www.usgs.gov

Telephone: 1-888-ASK-USGS

Any use of trade, product, or firm names is for descriptive purposes only and does not imply endorsement by the U.S. Government.

Although this report is in the public domain, permission must be secured from the individual copyright owners to reproduce any copyrighted materials contained within this report.

Suggested citation:

Garcia, A.M., 2009, Simulation of water quality in the Tull Creek and West Neck Creek watersheds, Currituck Sound basin, North Carolina and Virginia: U.S. Geological Survey Scientific Investigations Report 2008-5226, 22 p.

(only online at http://pubs.water.usgs.gov/sir2008-5226). 


\section{Contents}

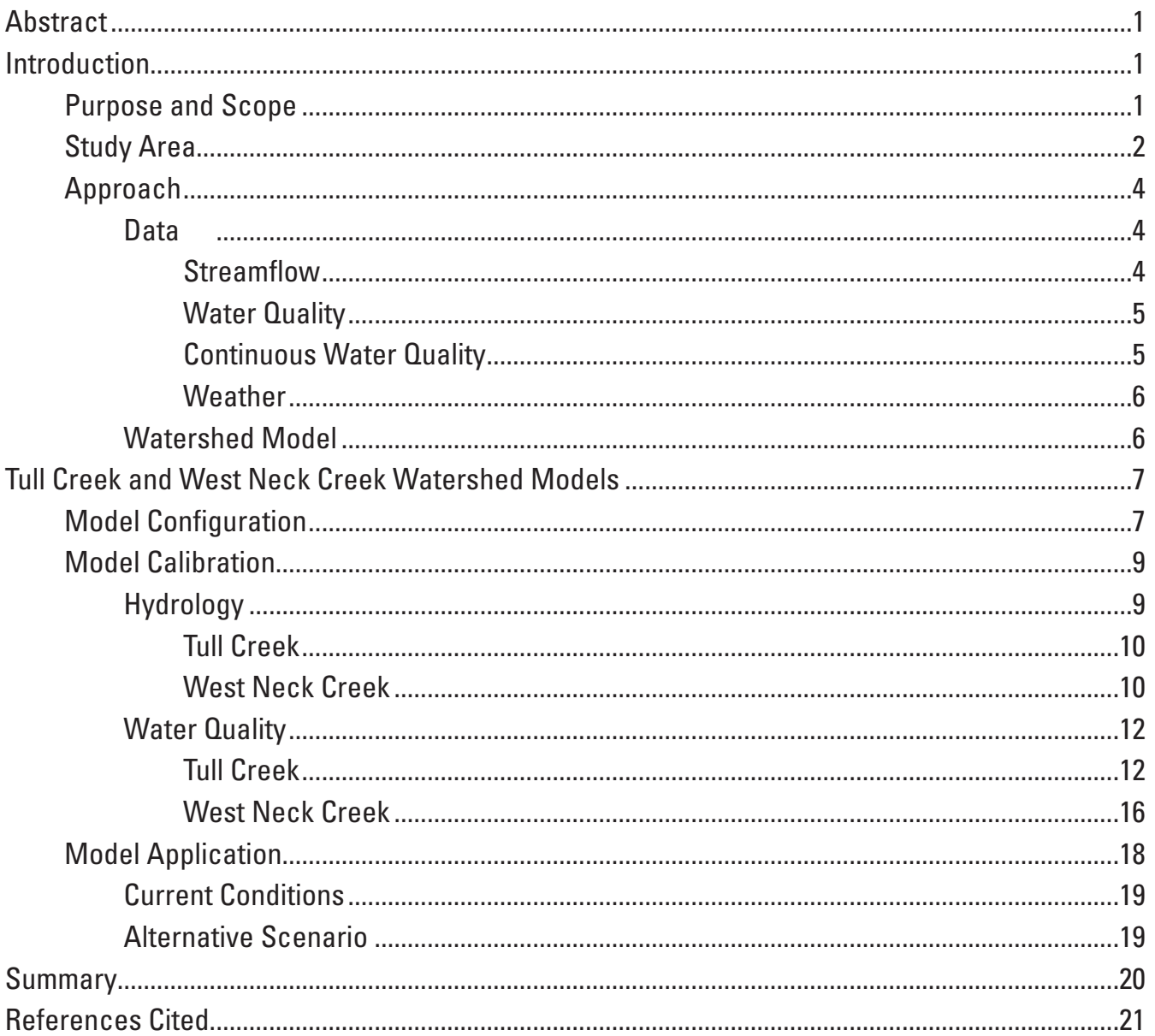

\section{Figures}

1. Map showing locations of Tull Creek and West Neck Creek watersheds, calibration sites, and weather stations used for model application, Currituck Sound basin, North Carolina and Virginia

2. Graph showing measured and net streamflow after application of a tidal filter for Tull Creek (USGS station 02043415)

3. Graph showing measured total suspended-solids concentrations and corresponding turbidity readings from August 1992 to August 2007 for tributaries to the Currituck Sound

4. Map showing subbasin delineation and spatial distribution of land use for the SWAT model of the (A) Tull Creek and (B) West Neck Creek watersheds.

5-13. Graphs showing:

5. Model results for Tull Creek hydrology: (A) simulated and observed flows for 19-month calibration period, (B) observed and simulated mean flows and best-fit line. 
6. Model results for West Neck Creek hydrology: (A) simulated and observed flows for 17-month calibration period, (B) observed and simulated mean

flows and best-fit line

7. Model results for Tull Creek total suspended-solids calibration: (A) simulated and observed concentrations, $(B)$ regression scatter plot of daily simulated and observed concentrations and best-fit line

8. Model results for Tull Creek total nitrogen calibration: (A) 7-day average simulated and observed concentrations, (B) regression scatter plot and best-fit lines.

9. Model results for Tull Creek dissolved phosphorus (P) calibration: (A) 15-day average simulated and observed concentrations, (B) 15-day average simulated and observed concentrations and best-fit line

10. Model results for West Neck Creek total suspended-solids calibration: (A) daily simulated and observed concentrations, (B) daily simulated and observed concentrations and best-fit line.

11. Model results for West Neck Creek total nitrogen (N) calibration: (A) 30-day average simulated and observed concentrations, (B) 30-day average simulated and observed concentrations and best-fit line

12. Model results for West Neck Creek dissolved phosphorus (P) calibration: (A) 30-day average simulated and observed concentrations, (B) 30-day average simulated and observed concentrations and best-fit line.

13. Average monthly percentage of reduction of total suspended solids, total nitrogen, and total phosphorus loads

\section{Tables}

1. Description of streamflow gages, water-quality sites, and weather stations selected for model application, Tull Creek and West Neck Creek watersheds, Currituck Sound basin, North Carolina

2. Crop rotation practice for row-crop agriculture within the study area as implemented in SWAT.

3. Model configured percent impervious area and directly connected impervious area for urban land-use categories.

4. Model parameter sensitivity rank for flow and total suspended solids (TSS), total nitrogen (TN) and total phosphorus (TP) concentrations and before and after values for the Tull Creek SWAT model calibration.

5. Water and total suspended-solids, total nitrogen, and total phosphorus concentrations yield estimates for 2006-2007 for the Tull Creek watershed.

6. Water and total suspended-solids, total nitrogen, and total phosphorus concentrations yield estimates for 2006-2007 for the West Neck Creek watershed .....20 


\section{Conversion Factors}

\section{SI to Inch/Pound}

\begin{tabular}{|c|c|c|}
\hline Multiply & By & To obtain \\
\hline \multicolumn{3}{|c|}{ Length } \\
\hline centimeter $(\mathrm{cm})$ & 0.3937 & inch (in.) \\
\hline millimeter $(\mathrm{mm})$ & 0.03937 & inch (in.) \\
\hline meter $(\mathrm{m})$ & 3.281 & foot $(\mathrm{ft})$ \\
\hline kilometer $(\mathrm{km})$ & 0.6214 & mile (mi) \\
\hline \multicolumn{3}{|c|}{ Area } \\
\hline hectare (ha) & 2.471 & acre \\
\hline hectare (ha) & 0.003861 & square mile $\left(\mathrm{mi}^{2}\right)$ \\
\hline square kilometer $\left(\mathrm{km}^{2}\right)$ & 247.1 & acre \\
\hline square kilometer $\left(\mathrm{km}^{2}\right)$ & 0.3861 & square mile $\left(\mathrm{mi}^{2}\right)$ \\
\hline \multicolumn{3}{|c|}{ Flow rate } \\
\hline cubic meter per second $\left(\mathrm{m}^{3} / \mathrm{s}\right)$ & 70.07 & acre-foot per day (acre-ft/d) \\
\hline cubic meter per second $\left(\mathrm{m}^{3} / \mathrm{s}\right)$ & 35.31 & cubic foot per second $\left(\mathrm{ft}^{3} / \mathrm{s}\right)$ \\
\hline \multicolumn{3}{|c|}{ Mass } \\
\hline $\operatorname{gram}(\mathrm{g})$ & 0.03527 & ounce, avoirdupois \\
\hline kilogram $(\mathrm{kg})$ & 2.205 & pound, avoirdupois \\
\hline \multicolumn{3}{|c|}{ Application rate } \\
\hline $\begin{array}{l}\text { kilograms per hectare per year } \\
{[(\mathrm{kg} / \mathrm{ha}) / \mathrm{yr}]}\end{array}$ & 0.8921 & $\begin{array}{l}\text { pounds per acre per year } \\
\text { [(lb/acre)/yr] }\end{array}$ \\
\hline
\end{tabular}

Temperature may be converted as follows:

$$
\begin{aligned}
& { }^{\circ} \mathrm{F}=\left(1.8 \times{ }^{\circ} \mathrm{C}\right)+32 \\
& { }^{\circ} \mathrm{C}=\left({ }^{\circ} \mathrm{F}-32\right) / 1.8
\end{aligned}
$$

Vertical coordinate information is referenced to the North American Vertical Datum of 1988 (NAVD 88). Horizontal coordinate information is referenced to the North American Datum of 1983 (NAD 83).

Concentrations of chemical constituents in water are given in milligrams per liter (mg/L). 


\title{
Simulation of Water Quality in the Tull Creek and West Neck Creek Watersheds, Currituck Sound Basin, North Carolina and Virginia
}

\author{
By Ana María García
}

\section{Abstract}

A study of the Currituck Sound was initiated in 2005 to evaluate the water chemistry of the Sound and assess the effectiveness of management strategies. As part of this study, the Soil and Water Assessment Tool (SWAT) model was used to simulate current sediment and nutrient loadings for two distinct watersheds in the Currituck Sound basin and to determine the consequences of different water-quality management scenarios. The watersheds studied were (1) Tull Creek watershed, which has extensive row-crop cultivation and artificial drainage, and (2) West Neck Creek watershed, which drains urban areas in and around Virginia Beach, Virginia.

The model simulated monthly streamflows with NashSutcliffe model efficiency coefficients of 0.83 and 0.76 for Tull Creek and West Neck Creek, respectively. The daily sediment concentration coefficient of determination was 0.19 for Tull Creek and 0.36 for West Neck Creek. The coefficient of determination for total nitrogen was 0.26 for both watersheds and for dissolved phosphorus was 0.4 for Tull Creek and 0.03 for West Neck Creek.

The model was used to estimate current (2006-2007) sediment and nutrient yields for the two watersheds. Total suspended-solids yield was 56 percent lower in the urban watershed than in the agricultural watershed. Total nitrogen export was 45 percent lower, and total phosphorus was 43 percent lower in the urban watershed than in the agricultural watershed. A management scenario with filter strips bordering the main channels was simulated for Tull Creek. The Soil and Water Assessment Tool model estimated a total suspended-solids yield reduction of 54 percent and total nitrogen and total phosphorus reductions of 21 percent and 29 percent, respectively, for the Tull Creek watershed.

\section{Introduction}

The Currituck Sound is a fragile natural resource that is threatened by human-induced changes in the Sound (Southwick and Norman, 2001). The urban areas in the Currituck
Sound basin, which include Virginia Beach, Virginia, and northwest Currituck County, North Carolina, are experiencing rapid population growth and associated increases in stormwater runoff and transport of sediment and nutrients loads from impervious areas. Extensive hydraulic modifications, including channelized waterways that connect the Currituck Sound to Chesapeake Bay, have altered the natural hydrology of the area. Furthermore, agricultural productivity in the region is facilitated by fertilizer applications and extensive ditch-drainage networks that increase nutrient delivery to the Sound.

A multiagency study of the Currituck Sound was initiated in 2005 with three goals: (1) to evaluate the water and salt balance of the Sound, (2) to assess the effect of potential management strategies on the Sound's water chemistry, quality, and resource viability, and (3) to develop a restoration plan. Partners in the effort included the U.S. Army Corps of Engineers (USCOE), North Carolina Division of Water Resources (NCDWR), Elizabeth City State University (ECSU), North Carolina National Estuarine Research Reserve (NC NERR), U.S. Fish and Wildlife Service (USFWS), and the U.S. Geological Survey (USGS). The study included data collection, watershed modeling, circulation and transport modeling, and development of a management plan for the Currituck Sound.

The role of the USGS in the study included collection of hydrologic and water-quality data, development and application of a watershed model, and support for the development of a circulation and transport model. The water-quality data collected provided the first comprehensive assessment of conditions in Currituck Sound in several years (Fine, 2008). The watershed model described in this report coupled with the circulation model can be used to assess land-based pollutant reduction strategies and is a tool available for policymakers and water-resource managers to use in managing Currituck Sound water quality.

\section{Purpose and Scope}

This report documents development, calibration, and application of the Soil and Water Assessment Tool (SWAT) 
model for two watersheds-Tull Creek and West Neck Creek - in the Currituck Sound drainage basin. The SWAT model was used to simulate flow and sediment and nutrient transport from these two watersheds to the Currituck Sound for existing conditions and one scenario. The available data limited the scope of the study to model calibration without model verification. For the Tull Creek watershed, hydrology was calibrated with data for the full period of record from January 2006 through July 2007, and water quality was calibrated using data from March 2006 through June 2007. For the West Neck Creek watershed, hydrology was calibrated for the period February 1998 through July 1999, and water quality was calibrated with a subset of available data for the period January 1, 1996, to September 30, 1999. The water-quality variables included total suspended solids, total phosphorus, and total nitrogen. The calibrated models were used to estimate loads under measured conditions and an alternative scenario for 2006-2007.

This study follows one of six themes outlined in the science strategy of the USGS: "to inform the public and decision makers about ... forecasts of likely outcomes for water availability, water-quality, and aquatic ecosystem health caused by changes in land use and land cover, natural and engineered infrastructure, water use, and climate" (U.S. Geological Survey, 2007a). The study also provides support to the USCOE, the NCDWR, and the USFWS in addressing at least three of the Water Resources Discipline Fiscal Year 2007 Federal-State Cooperative Program priority issues: (1) water quality, (2) water resources in the coastal zone, and (3) wetlands, lakes, reservoirs, and estuaries (U.S. Geological Survey, 2007b).

\section{Study Area}

The Currituck Sound basin is located in northeast North Carolina and southeast Virginia in the Coastal Plain Physiographic Province (fig. 1). The area has little topographic relief, and natural channels have been extensively dredged and modified such that at least one canal connects Currituck Sound to Chesapeake Bay. Agricultural areas are characterized by extensive networks of agricultural ditches. The exact drainage area of Currituck Sound basin, which is estimated to be 1,900 square kilometers $\left(\mathrm{km}^{2}\right)$, is uncertain because of these hydrologic modifications (Caldwell, 2001).

The climate of the study area is temperate and oceanic. The annual average precipitation is about 114 centimeters (cm), and monthly totals typically are greatest during July and August. Flood-producing rainfall and high winds associated with hurricanes or tropical storms and convective thunderstorms occur during the summer and fall. In addition, northeasters can generate strong winds, heavy rainfall, and high water conditions or flooding during fall and winter months.

There are three major natural tributaries to Currituck Sound: North Landing River, Tull Creek, and Northwest River (fig. 1). All of the tributaries have tidally influenced zones where the astronomical and wind tides in the sound affect streamflow and water quality. Most of the land that drains to the North Landing River and Northwest River is located in the cities of Virginia Beach and Chesapeake, Virginia. Tull Creek watershed is located in Camden and Currituck Counties, in northwest North Carolina, a productive agricultural region.

To compare loading and hydrology of two distinct watersheds within the Currituck Sound basin, the SWAT model was applied to Tull Creek, a predominantly agricultural basin that drains to Currituck Sound, and West Neck Creek, a largely urban basin that is a tributary to the North Landing River. Based on the 2001 National Land Cover Dataset (Homer and others, 2004), 31 percent of the Tull Creek watershed area was in intensive row-crop agriculture and 24 percent was in pasture or hay production (Homer and others, 2004). The watershed also has large amounts of marshland ( 25 percent) and forest (18 percent) that buffer the main channels and the outlet to the Sound. Land use in the West Neck Creek is 36 percent urban and 37 percent agricultural. Like Tull Creek, wetlands and forest (27 percent) buffer the southern portion of the creek.

Predominant soils in Tull Creek watershed belong to the Argent and Pungo soil series. The Argent series are fine, mixed and active thermic typic endoaqualfs. The Pungo soil series are dysic and thermic typic haplosaprists (Natural Resources Conservation Service, 2008). The Argent series consists of very deep, poorly or very poorly drained, slowly permeable soils formed in clayey marine sediments. Pungo series soils are poorly drained muck soils composed of remains of vegetation over loamy and clayey marine sediments. Agricultural production in these soils has been made possible by extensive ditch-drainage systems. These ditches have altered the connection between the main waterways and the natural flood plain and make the exact drainage area of the watershed, which based on topography alone is estimated to be $150 \mathrm{~km}^{2}$, uncertain.

West Neck Creek watershed, as defined topographically by the confluence to the North Landing River, is estimated to be $87 \mathrm{~km}^{2}$ and lies in the northern portion of the Currituck Sound basin, within heavily developed areas of Virginia Beach, Virginia, and includes a substantial portion of the Oceana Naval Air Station (Bales and Skrobialowski, 1994). The Portsmouth soils series is dominant in the basin. These are fine-loamy, over sandy or sandy-skeletal, mixed and semi-active, thermic typic umbraquults formed in loamy marine or fluvial sediments. These soils are moderately well drained with moderate infiltration rates that facilitate groundwater recharge.

West Neck Creek has been channelized such that it provides a hydraulic connection between the North Landing River and Chesapeake Bay. Flow can be affected by tides along the entire reach of the creek and can be in either a northerly or southerly direction with the southerly flow direction predominating 68 percent of the time. Wind direction and speed influence flow; precipitation alone has little effect on flow (Caldwell, 2001). 


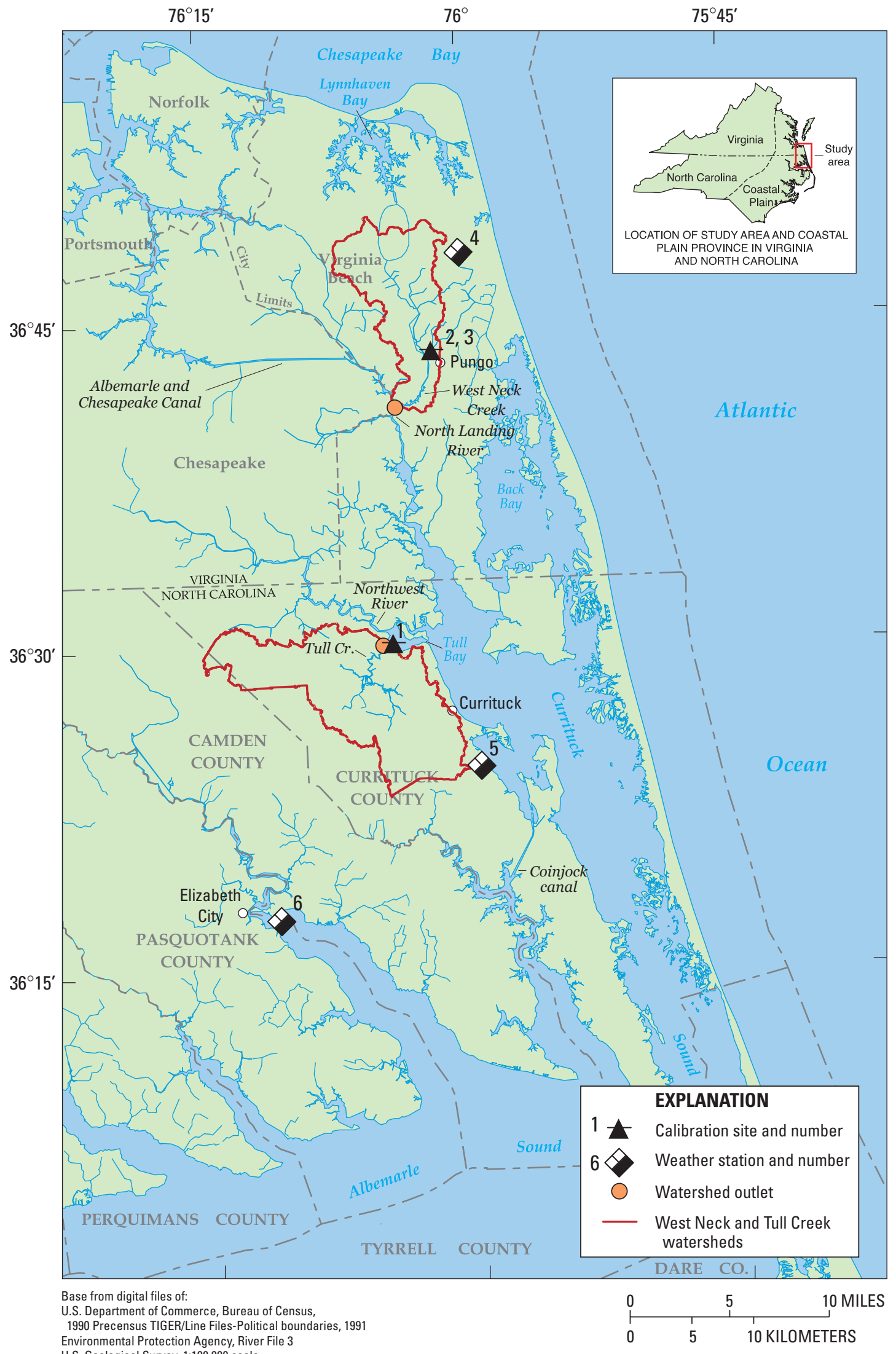

.

Figure 1. Locations of Tull Creek and West Neck Creek watersheds, calibration sites, and weather stations used for model application, Currituck Sound basin, North Carolina and Virginia. 


\section{Approach}

The SWAT watershed model was selected for this study because it was designed to simulate management effects on water and pollutant transport for gaged and ungaged watersheds across the United States (Gassman and others, 2007). The model was developed by the Agricultural Research Service of the U.S. Department of Agriculture (USDA) as a tool for assessing water-resource and nonpoint-source pollution problems (Arnold and others, 1998). SWAT also is part of the U.S. Environmental Protection Agency (USEPA) Better Assessment Science Integrating Point and Nonpoint Sources (BASINS) suite of models. The SWAT model can be used to predict the effect of changing agricultural management practices on water quality and can be used to develop alternative management scenarios. The model can simulate the effect that artificial drainage networks have on hydrology and water quality, an important feature in the Tull Creek watershed.

\section{Data}

Data required for the modeling effort included daily streamflow for hydrologic calibration, sediment and nutrient data for water-quality calibration, and daily precipitation and temperature for model input. Calibration sites were chosen on the basis of the extent of record (table 1) for streamflow and water-quality data as well as proximity to the watershed outlet (fig. 1). Weather stations were chosen on the basis of their proximity to the center of each study watershed.

\section{Streamflow}

The Tull Creek watershed model was calibrated with streamflow data recorded continuously at the Secondary Road 1222 bridge (USGS station number 02043415) streamgage from January 2006 to July 2007. The West Neck Creek watershed model was calibrated using data from earlier studies at the Indian River Road Bridge in Virginia Beach (USGS station number 02043200) streamgage. Discharge data were collected continuously from February 1998 through July 1999 for a study of hydrologic and salinity characteristics of Currituck Sound and selected tributaries (Caldwell, 2001).

The streamgages used to collect the data for model calibration of both watersheds were located within the zone of tidal influence of each stream, and the extent of the zone was unknown in both cases. Both positive and negative flows were recorded at the gages. The net streamflow at the streamgage was estimated using a low-pass tidal filter, which removes the effects of astronomical tides from the streamflow record. To illustrate, streamflows measured at Tull Creek (fig. 2) were positive 57 percent of the time for the 2006-2007 calibration period and increased to 61 percent of the time after application of the tidal-filter; however, negative flow remained in the extracted net streamflow, suggesting slow-moving water and a wind-dominated system. Because the SWAT model does not account for upstream flow, the calibration was performed only to positive flow values obtained from the tidal-filter analysis.

Table 1. Description of streamflow gages, water-quality sites, and weather stations selected for model application, Tull Creek and West Neck Creek watersheds, Currituck Sound basin, North Carolina.

[SR, Secondary Road; Rd, road]

\begin{tabular}{|c|c|c|c|c|c|c|c|}
\hline $\begin{array}{c}\text { Map } \\
\text { no. } \\
\text { (fig. 1) }\end{array}$ & $\begin{array}{l}\text { Station } \\
\text { identifier }\end{array}$ & Station name & Latitude & Longitude & Data collected & Period of record & $\begin{array}{l}\text { Data-collection } \\
\text { interval }\end{array}$ \\
\hline \multirow[t]{3}{*}{1} & $02043415^{a}$ & $\begin{array}{l}\text { Tull Creek at SR } 1222 \\
\text { Bridge }\end{array}$ & $36^{\circ} 29^{\prime} 47^{\prime \prime}$ & $76^{\circ} 05^{\prime} 03^{\prime \prime}$ & Discharge & $1 / 2006$ to $7 / 2007$ & Continuous \\
\hline & & & & & Turbidity & $3 / 2006$ to $6 / 2007$ & Continuous \\
\hline & & & & & Nutrients & $7 / 2006$ to $6 / 2007$ & Semi-monthly \\
\hline 2 & $02043200^{\mathrm{a}}$ & $\begin{array}{l}\text { West Neck Creek at Indian } \\
\text { River Rd }\end{array}$ & $36^{\circ} 43^{\prime} 16^{\prime \prime}$ & $76^{\circ} 02^{\prime} 03^{\prime \prime}$ & Discharge & $2 / 1998$ to $7 / 1999$ & Continuous \\
\hline 3 & $5 \mathrm{BWNC} 0-3.65^{\mathrm{b}}$ & $\begin{array}{l}\text { West Neck Creek at Indian } \\
\text { River Rd }\end{array}$ & $36^{\circ} 43^{\prime} 16^{\prime \prime}$ & $76^{\circ} 02^{\prime} 03^{\prime \prime}$ & $\begin{array}{l}\text { Turbidity, } \\
\text { Nutrients }\end{array}$ & $6 / 1972$ to $1 / 2006$ & Monthly \\
\hline 4 & $\mathrm{KNTU}^{\mathrm{c}}$ & Oceana Naval Air Station & $36^{\circ} 49^{\prime} 15^{\prime \prime}$ & $76^{\circ} 02^{\prime} 01^{\prime \prime}$ & $\begin{array}{l}\text { Precipitation, } \\
\text { Temperature }\end{array}$ & $\begin{array}{l}\text { 3/1945 to current } \\
\text { year }\end{array}$ & Continuous \\
\hline 5 & $332895^{\mathrm{c}}$ & $\begin{array}{l}\text { Currituck Airport weather } \\
\text { station }\end{array}$ & $36^{\circ} 23^{\prime} 56^{\prime \prime}$ & $76^{\circ} 00^{\prime} 57^{\prime \prime}$ & $\begin{array}{l}\text { Precipitation, } \\
\text { Temperature }\end{array}$ & $\begin{array}{l}\text { 2/2004 to current } \\
\text { year }\end{array}$ & Continuous \\
\hline 6 & $312719^{d}$ & $\begin{array}{l}\text { Elizabeth City weather } \\
\text { station }\end{array}$ & $36^{\circ} 18^{\prime} 35^{\prime \prime}$ & $76^{\circ} 12^{\prime} 18^{\prime \prime}$ & $\begin{array}{l}\text { Precipitation, } \\
\text { Temperature }\end{array}$ & $1 / 1934$ to $10 / 2007$ & Continuous \\
\hline
\end{tabular}

${ }^{\mathrm{a}}$ Data collected by the U.S. Geological Survey.

${ }^{\mathrm{b}}$ Data collected by Virginia Department of Environmental Quality.

${ }^{\mathrm{c}}$ Data collected by the Federal Aviation Administration.

${ }^{\mathrm{d}}$ Data collected by the National Weather Service. 


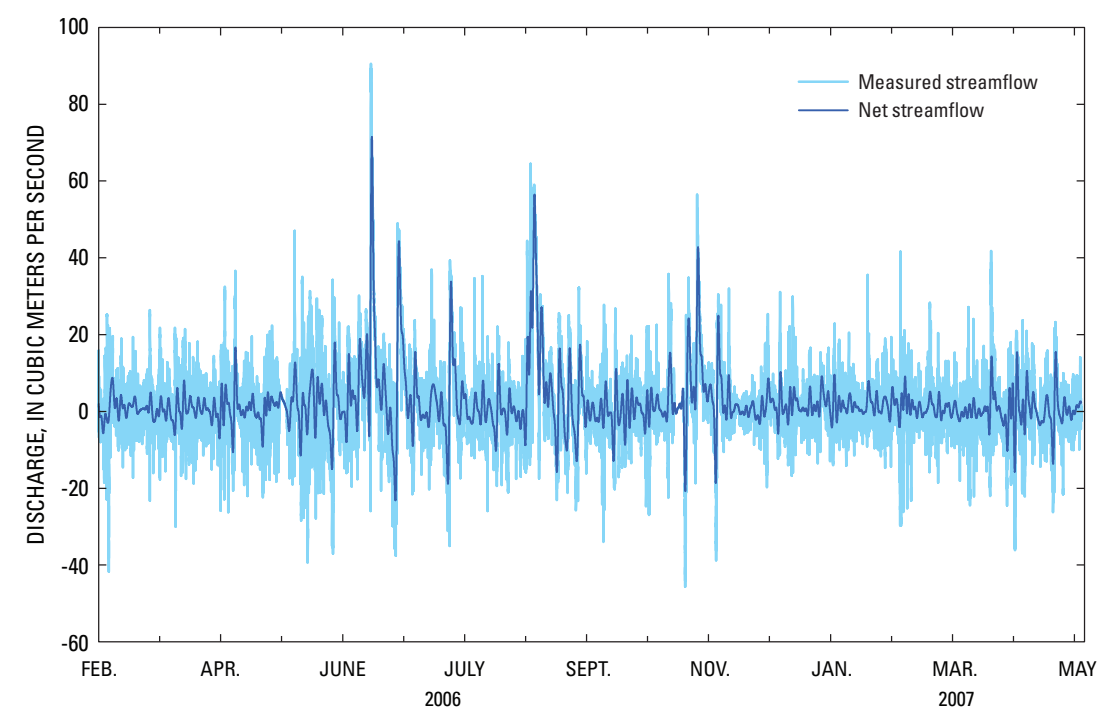

Figure 2. Measured and net streamflow after application of a tidal filter for Tull Creek (USGS station 02043415).

\section{Water Quality}

Water-quality data collected during 2006-2007 (Fine, 2008) were used to calibrate the Tull Creek model. Field monitors continuously recorded turbidity, temperature, $\mathrm{pH}$, and specific conductance and dissolved-oxygen concentrations during the same period. Semi-monthly water samples were collected from July 2006 to June 2007 and were analyzed by the University of North Carolina at Chapel Hill Institute of Marine Sciences (IMS) for several constituents, including organic and inorganic nitrogen, orthophosphate, and total suspended solids.

Water-quality samples are collected by the Virginia Department of Environmental Quality (VDEQ) at the Indian River Road Bridge streamgage as part of their water-quality monitoring program (Virginia Department of Environmental Quality, 2007). Samples are collected monthly and analyzed by VDEQ for several constituents, including turbidity, total nitrogen, and dissolved phosphorus. The observed data used to calibrate the West Neck Creek model were collected from January 1996 to November 2000.

\section{Continuous Water Quality}

Measurements of turbidity were made over a longer period of time than were total suspended-solids (TSS) concentrations at both calibration sites. In order to use the longer record, TSS concentrations were estimated from turbidity data by establishing a relation between the two properties. Typically, this kind of analysis is site-specific, but because the number of samples at individual Currituck Sound tributaries was limited, the analysis was performed using data from all tributaries. Data included measurements made during 2006-2007 and historical monitoring (1992-1999). To obtain a relation, a linear regression was performed on the 120 paired observations. The analysis was similar to one performed for tidal creeks in Great Bay, New Jersey (Suk and others, 1998), which derived a linear relation when comparing continuous turbidity measurements to 593 TSS concentration measurements. For the present study, the least-squares regression performed (fig. 3) showed a correlation between TSS concentrations in milligrams per liter $(\mathrm{mg} / \mathrm{L})$ and a daily

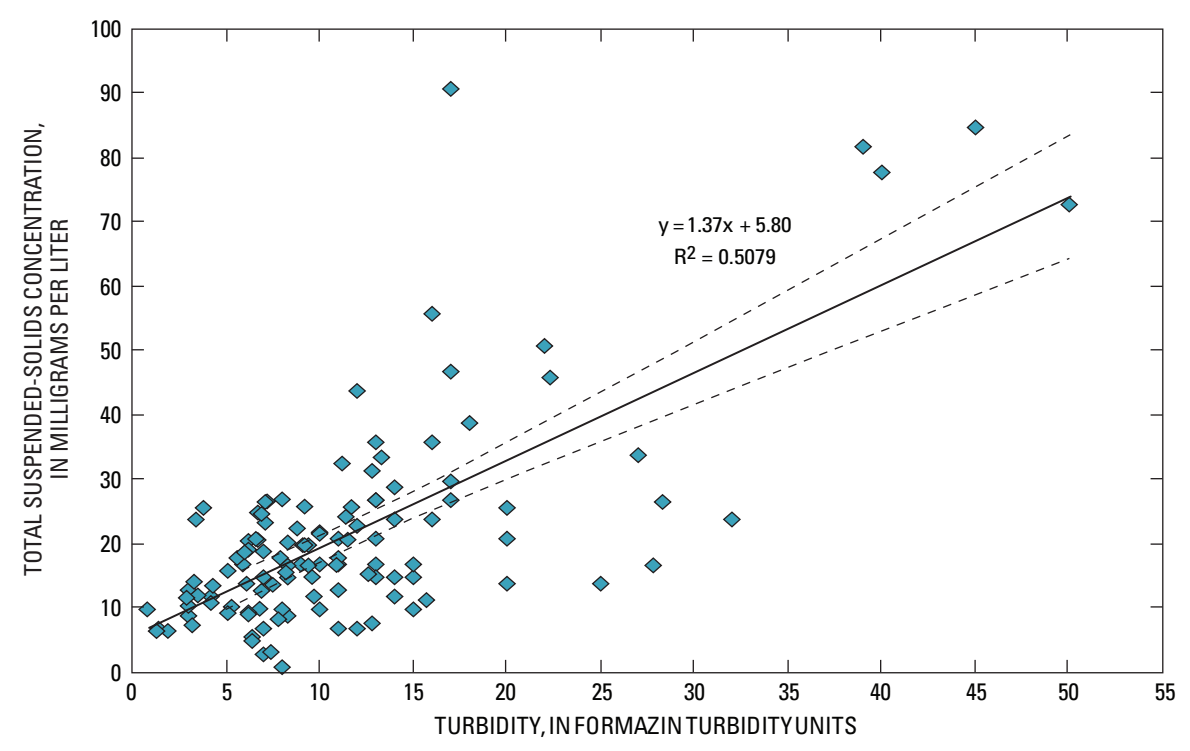

Figure 3. Measured total suspended-solids concentrations and corresponding turbidity readings from August 1992 to August 2007 for tributaries to the Currituck Sound $(n=120)$. The solid line represents the linear regression, and the dashed lines represent the 95-percent confidence interval. 
mean of turbidity readings in formazin turbidity units (FTU). The relation is given by

$$
\text { TSS }(\mathrm{mg} / \mathrm{L})=1.4 \text { Turbidity }(\text { FTU })+5.8
$$

with a coefficient of determination $\left(\mathrm{R}^{2}\right)$ of 0.508 . Measurements of TSS concentrations were expanded from 10 to 362 for the Tull Creek watershed and from 15 to 53 for the West Neck Creek watershed by using equation (1). These expanded data sets were used for model calibration.

\section{Weather}

Weather data are required as input to the SWAT model, including daily precipitation, temperature, relative humidity, solar radiation, and wind speed. Daily precipitation and temperature data were obtained from the National Climatic Data Center (NCDC) and the North Carolina State Climate Office. The Currituck Airport cooperative weather station (COOP 332895) is located approximately 13 kilometers $(\mathrm{km})$ from the center of the Tull Creek watershed (fig. 1). No other station was located near enough to the Tull Creek watershed for spatial interpolation to be performed; therefore, daily precipitation and temperature data obtained from the station were used directly as input for the entire watershed. The Elizabeth City cooperative weather station (COOP 312719) is located approximately $19 \mathrm{~km}$ from the center of the watershed, and data collected at the station were used to fill in missing records such that the total weather data file for Tull Creek spanned the calibration period as well as 2 years for model initialization (2004-2007). For the West Neck Creek model, daily precipitation and temperature data were obtained from the Oceana Naval Air Station, which is located within the watershed. The data were used as input to the model for the calibration and application period (1996-2007).

For both watershed models, daily relative humidity, solar radiation, and wind speed were predicted with the SWAT model by using a built-in weather generator. The model generated the additional weather parameters by using historical data and trends collected from surrounding National Weather Service stations (Neitsch and others, 2005).

\section{Watershed Model}

The SWAT model is a process-based, semi-distributed model that requires a delineated watershed to be divided into small catchments or subbasins, each identified by a single reach. Each subbasin is further subdivided into hydrologic response units, which consist of unique combinations of land use, management practices, and soil properties. Physical processes, such as hydrology, plant growth, nutrient cycling, and constituent transport, can be simulated for each hydrologic response unit. The resulting water and material loads are aggregated within their corresponding subbasins and allocated to the subbasin reach. Discharge and fluxes are kinematically routed downstream from upstream reaches to the watershed outlet while accounting for in-stream processes. Model output includes hydrographs for any discharge point that defines a subbasin, including the delineated watershed outlet.

The hydrologic component of SWAT uses the curvenumber runoff equation developed by the Natural Resources Conservation Service (Soil Conservation Service, 1986). The curve-number method is empirically based and relates runoff potential to land cover and soil characteristics. High curve numbers translate into greater runoff. Erosion is estimated using the modified Universal Soil Loss Equation (Williams and Berndt, 1977), which predicts erosion rates based on rainfall pattern, soil type, topography, crop system, and management practices. In-stream transformations, kinetics of algae growth, nitrogen and phosphorus cycling, carbonaceous biological oxygen demand, and dissolved-oxygen concentrations are based on routines developed for the QUAL2E model (Brown and Barnwell, 1987).

The SWAT model can be executed from within a geographic information system (GIS), which incorporates spatially distributed data. For this study, the ArcSWAT version 1.0.7 (Winchell and others, 2007) model, which is embedded with ArcGIS 9, was used to execute SWAT. Several digital spatial data sets, including elevation, land-use, soils, and climatic data, were used by ArcSWAT to partition the watershed into subbasins, determine the channel network, and configure the model input.

To date, no absolute criteria for judging SWAT performance have been firmly established in the literature. Model performance commonly is evaluated with several criteria for goodness-of-fit: graphical comparison, the regression correlation coefficient $\left(\mathrm{R}^{2}\right)$, and the Nash-Sutcliffe model efficiency (E) coefficient (Nash and Sutcliffe, 1970). The $\mathrm{R}^{2}$ value measures how well the simulated and observed regression lines approach an ideal match and range from zero to 1 , with a value of zero indicating no correlation and a value of 1 indicating that the simulated values equal the corresponding measured values. The efficiency coefficient is calculated by

$$
E=1-\frac{\sum_{t=1}^{T}\left(Q_{0}^{t}-Q_{m}^{t}\right)^{2}}{\sum_{t=1}^{T}\left(Q_{0}^{t}-\bar{Q}_{0}\right)^{2}},
$$

where $Q_{0}^{t}$ is the observed quantity at time, $t ; Q_{m}^{t}$ is the simulated quantity; and $\bar{Q}_{0}$ is the average of the observed quantity. The coefficient can range from -1 to 1 . An efficiency of 1 corresponds to a perfect match of simulated to observed data. An efficiency of zero indicates that the model predictions are as accurate as the mean of the observed data, and efficiency less than zero occurs when the observed mean is a better predictor than the model.

Moriasi and others (2007) proposed that E values should exceed 0.5 for model results to be considered satisfactory 
for hydrologic and water-quality calibrations performed on a monthly time step. Gassman and others (2007) used 0.5 for both $\mathrm{E}$ and $\mathrm{R}^{2}$ values for all time steps to compare results across various SWAT applications.

\section{Tull Creek and West Neck Creek Watershed Models}

The configuration of the Tull Creek and West Neck Creek watershed models are described in this section. Calibration procedures and results for both models are described, including an application of the calibrated Tull Creek model.

\section{Model Configuration}

Individual SWAT models were developed for each of the study watersheds. Watershed delineations were performed using ArcSWAT to divide each watershed into subbasins. The level of subbasin delineation was based on the minimum drainage area required to form the origin of a stream. This threshold depended on the resolution of the elevation data. For this study, high-resolution digital elevation models (DEMs) served as the basis for subbasin definition, which allowed for the use of a detailed description of watershed topography, including hydrologic modifications such as ditches. This level of detail played an important role in determining the stream network in these lowrelief watersheds.

For Tull Creek watershed, light detection and ranging (LiDAR) data with a vertical accuracy of about $25 \mathrm{~cm}$ were used to delineate subbasins (North Carolina Division of Emergency Management, 2002). Because of the extensive ditch-drainage network through the Tull Creek watershed, the drainage area obtained using LiDAR data was supplemented by delineation performed by the Natural Resources Conservation Service (Natural Resources Conservation Service, 2007). The watershed that was delineated to the Tull Creek streamgage had 116 subbasins that ranged in area from 0.45 to 476 hectares (ha) and a total watershed area of $150 \mathrm{~km}^{2}$ (fig. 4A).

Delineation of the West Neck Creek watershed presented challenges, as there is a basin outlet at the northern and southern end. A previous study (Bales and Skrobialowski, 1994) found that daily mean flow was to the south 64 percent of the time. Hence, the watershed outlet was defined at the southern end, at the confluence with the North Landing River. Delineation was performed using a 10-meter (m) DEM which resulted in 93 subbasins ranging in area from 0.88 to 318 ha and a total delineated drainage area of $88 \mathrm{~km}^{2}$ (fig. 4B). One of the subbasins was defined by the location of the calibration streamgage, located $10 \mathrm{~km}$ upstream from the watershed outlet. The model was configured to represent the northern outlet as a calibrated point source.

Overlays of the land-cover data and soil characteristics were used to define hydrologic response units for each of the subbasins. Model parameters were configured to represent the best information on existing land-management practices for each hydrologic response unit. Land-use data for both watersheds were derived from the 2001 National Land-Cover Dataset (Homer and others, 2004), and soil layers were obtained from the STATSGO database (U.S. Department of Agriculture, 1995). Based on county-level information provided in the 2002 Census of Agriculture (U.S. Department of Agriculture, 2002), agricultural hydrologic response units were configured to represent 2-year rotations of corn and soybeans with wheat as a winter crop (table 2). Land treatment included fall and spring tillage, just before planting. Fertilizer application was set to rates commonly used by growers in eastern North Carolina. The model was set so that just before planting, 17 kilograms per hectare $(\mathrm{kg} / \mathrm{ha})$ of nitrogen, $33 \mathrm{~kg} / \mathrm{ha}$ of phosphorus, and $100 \mathrm{~kg} / \mathrm{ha}$ of potassium all were applied to corn, soy bean, and wheat fields. An additional $110 \mathrm{~kg} / \mathrm{ha}$ of nitrogen fertilizer was configured for the growing season for corn (Hardy and others, 2003).

Table 2. Crop rotation practice for row-crop agriculture within the study area as implemented in SWAT.

[Each ground cover is represented by crop. The time interval for each crop is determined by the planting and harvest operations. $\mathrm{kg} / \mathrm{ha}$, kilogram per hectare]

\begin{tabular}{|c|c|c|c|}
\hline $\begin{array}{c}\text { Rotation } \\
\text { year }\end{array}$ & $\begin{array}{l}\text { Operation } \\
\text { start date }\end{array}$ & Crop & Simulated operation \\
\hline 1 & January 1 & Winter wheat & Planting $^{\mathrm{a}}$ \\
\hline 1 & May 2 & Winter wheat & Harvest \\
\hline 1 & May 3 & Corn & Tillage \\
\hline 1 & May 5 & Corn & Fertilizer application $^{\mathrm{b}}$ \\
\hline 1 & May 10 & Corn & Planting \\
\hline 1 & June 1 & Corn & Fertilizer application $^{c}$ \\
\hline 1 & October 15 & Corn & Harvest \\
\hline 1 & October 20 & Winter wheat & Planting \\
\hline 1 & December 21 & Winter wheat & Harvest \\
\hline 2 & January 1 & Winter wheat & Planting $^{\mathrm{a}}$ \\
\hline 2 & May 2 & Winter wheat & Harvest \\
\hline 2 & May 3 & Soybean & Tillage \\
\hline 2 & May 5 & Soybean & Fertilizer application ${ }^{\mathrm{b}}$ \\
\hline 2 & May 10 & Soybean & Plant begin \\
\hline 2 & October 15 & Soybean & Harvest \\
\hline 2 & October 20 & Winter wheat & Fertilizer application ${ }^{\mathrm{b}}$ \\
\hline 2 & October 20 & Winter wheat & Planting \\
\hline 2 & December 31 & Winter wheat & Harvest \\
\hline
\end{tabular}

${ }^{a}$ This operation is necessary for SWAT to simulate continuous winter wheat growth over the rotation year.

b 5-10-30 starter fertilizer ( $5 \%$ nitrogen as $\mathrm{N}, 10 \%$ phosphorus as $\mathrm{P}_{2} \mathrm{O}_{5}$, and $30 \%$ potassium as $\mathrm{K}_{2} \mathrm{O}$ ) was applied at $330 \mathrm{~kg} / \mathrm{ha}$.

c 30-0-0 in-season fertilizer was applied at $375 \mathrm{~kg} / \mathrm{ha}$. 
A.

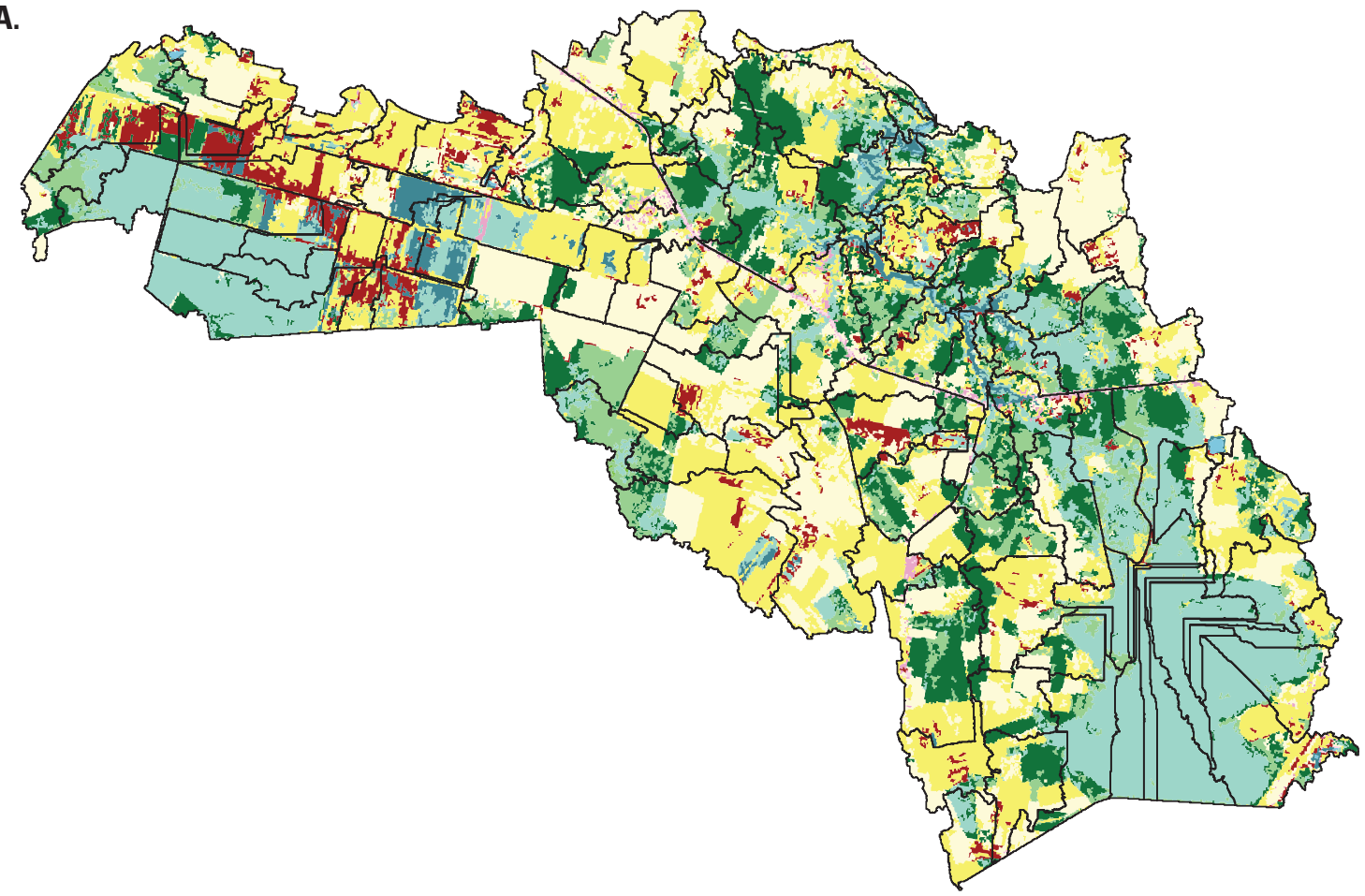

B.

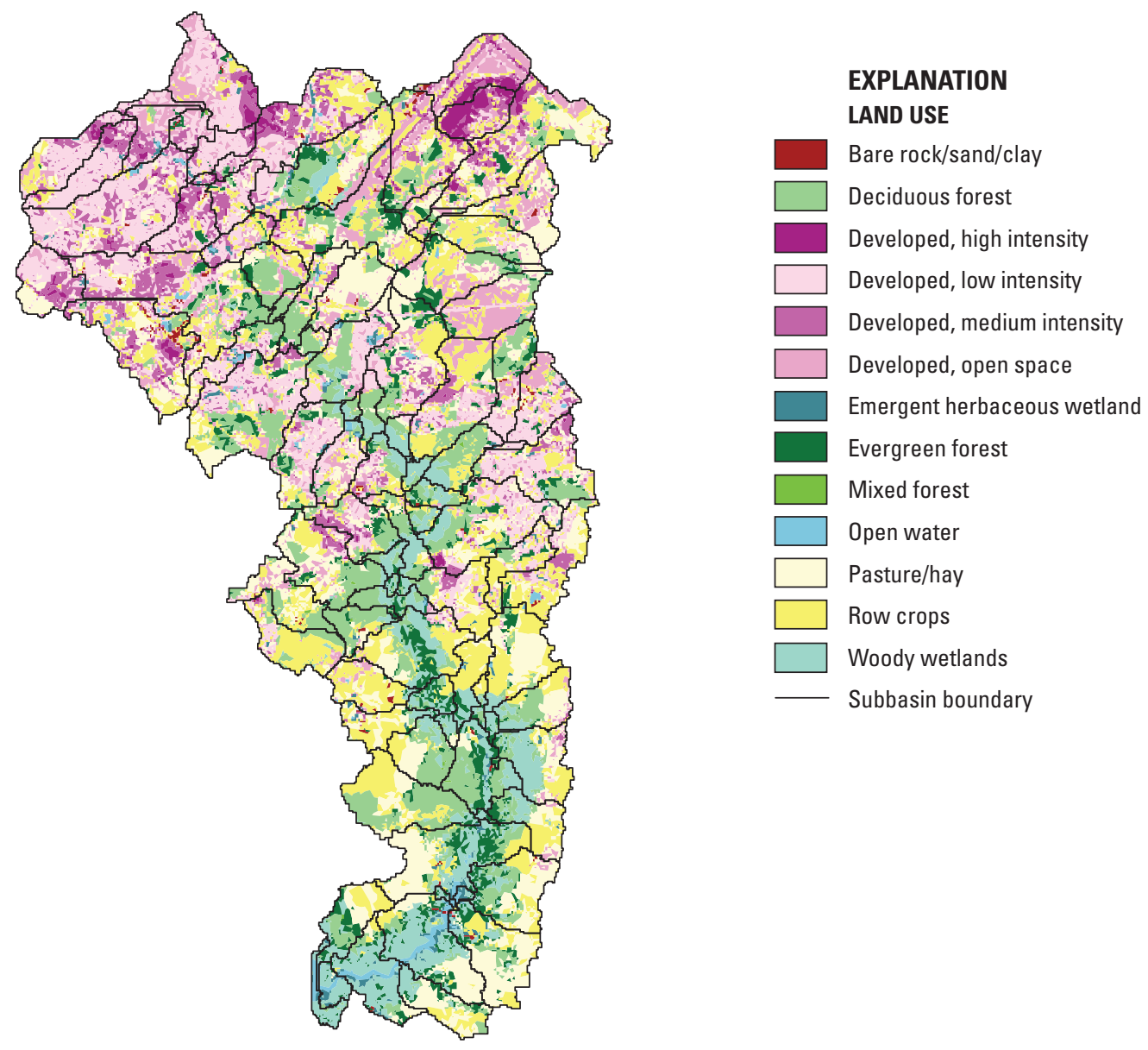

Figure 4. Subbasin delineation and spatial distribution of land use for the SWAT model of the (A) Tull Creek and (B) West Neck Creek watersheds. 
Another important consideration in the model configuration was the representation of the ditch-drainage networks. The SWAT model permits simulation of flow and nutrient transport in tile- or ditch-drained areas. Precipitation is routed to the streams through the ditches rather than running over land, which results in shorter travel times and less opportunity for chemical constituents to migrate into shallow ground water or be biologically assimilated. For each agricultural land class in the Tull Creek model, a network of 1.2-m-deep drainage ditches and a restrictive soil layer of $6 \mathrm{~m}$ were assumed. These values are consistent with documented practices and characteristics in the Coastal Plain (Evans and others, 2007). Ditch drainage was not simulated for the West Neck Creek watershed because the soils are well drained.

Urban areas of the West Neck Creek watershed were configured by defining the percent of impervious area for each land class. In order to simulate storm drainage, a percentage of impervious surface was assumed to be directly connected with the stream system (table 3 ). These values were based on values reported in other SWAT applications (Neitsch and others, 2005). Bermuda grass was assumed to grow in pervious urban land areas. Point sources are also an important feature in urban areas. Oceana Naval Air Station (NPDES 0005266) discharges wastewater into West Neck Creek. This point source was added to the model, and actual flow and loading data were obtained from the VDEQ (M. Hollis, Virginia Department of Environmental Quality, written commun., 2007). An additional point source was configured to account for delivery of nutrients from parts of Virginia Beach not within the topographic watershed boundary. Reported loads and flows associated with the point source were assigned during calibration.

Table 3. Model configured percent impervious area and directly connected impervious area for urban land-use categories.

\begin{tabular}{lcc}
\hline \multicolumn{1}{c}{ Land-use name } & $\begin{array}{c}\text { Percent } \\
\text { impervious } \\
\text { area }\end{array}$ & $\begin{array}{c}\text { Percent directly } \\
\text { connected } \\
\text { impervious area }\end{array}$ \\
\hline Residential-High Density & 60 & 32 \\
Residential-Medium Density & 38 & 12 \\
Residential-Low Density & 12 & 30 \\
Commercial & 67 & 62 \\
Industrial & 84 & 79 \\
\hline
\end{tabular}

\section{Model Calibration}

Model calibration was approached systematicallyhydrology was calibrated before water-quality components. Simulated and observed streamflow and TSS concentrations were calibrated on a daily time step. Total nitrogen was calibrated by simulating individual components (nitrate, nitrite, organic nitrogen, and ammonia) and comparing 7-day moving averages for observed and simulated total nitrogen. Dissolved phosphorus was the only form of phosphorus calibrated because of the limited available data. Observed and simulated dissolved phosphorus concentrations were compared using 7-day moving averages. The 7-day moving average was appropriate to compare daily simulation output to observed data obtained at semi-monthly and monthly sampling intervals.

Calibration was facilitated by identifying relevant parameters and performing a sensitivity analysis (table 4). Because of data availability and the extensive parameter set associated with non-urban land-use categories in SWAT, the sensitivity analysis was performed for the Tull Creek watershed only. The SWAT sensitivity analysis algorithm employs a method that combines the one-factor-at-a-time design with latin-hypercube sampling (Holvoet and others, 2005). In this approach, the effect of changing values of each model parameter on the model outputs is evaluated one at a time. The analysis results in rankings based on sensitivity indexes. Based on these rankings, the most sensitive parameters were identified and modified within suggested value ranges.

Calibration was performed first for the Tull Creek watershed by adjusting hydrologic response unit parameters until simulated and observed discharge, nitrogen component, and dissolved phosphorus concentrations were in agreement at the calibration point, the streamgage at Secondary Road 1222 bridge (site 1). Calibrated parameters for agricultural land-use categories in Tull Creek subsequently were applied to the West Neck Creek watershed. Urban and in-stream parameters were then modified to simulate observed flow and nutrient fluxes in West Neck Creek at the Indian River Road bridge streamgage (site 2).

Different criteria were used to determine if a calibration was successful for hydrologic and water-quality simulations. For the hydrologic calibrations, both $\mathrm{R}^{2}$ and $\mathrm{E}$ were computed for monthly time steps, and a calibration criterion of 0.5 for both terms was used. Total suspended-solids calibrations were evaluated on a daily time step, and the $\mathrm{R}^{2}$ calibration criterion was relaxed to 0.2 , reflecting the smaller time interval. Similarly, water-quality calibrations were considered satisfactory with $\mathrm{R}^{2}$ above 0.2 computed on the 7-day moving average. The lower $\mathrm{R}^{2}$ for water quality also accounted for several limitations: data available for model evaluation are not representative of a variety of conditions, and the model does not simulate backflow or zero flow by predicting pollutant transport at times when existing flows may have been negative or zero.

\section{Hydrology}

Hydrologic calibration was performed by adjusting parameters, such as curve numbers, and comparing continuous data from the streamgaging station to simulated daily flow. Key considerations in the hydrologic calibration were the overall water balance, the high-flow to low-flow distribution, stormflows, and seasonal variation. 
Table 4. Model parameter sensitivity rank for flow and total suspended solids (TSS), total nitrogen (TN), and total phosphorus (TP) concentrations and before and after values for the Tull Creek SWAT model calibration.

[-, no sensitivity to parameter; $\mathrm{mg} / \mathrm{L}$, milligram per liter; $\mathrm{mm}$, millimeter $]$

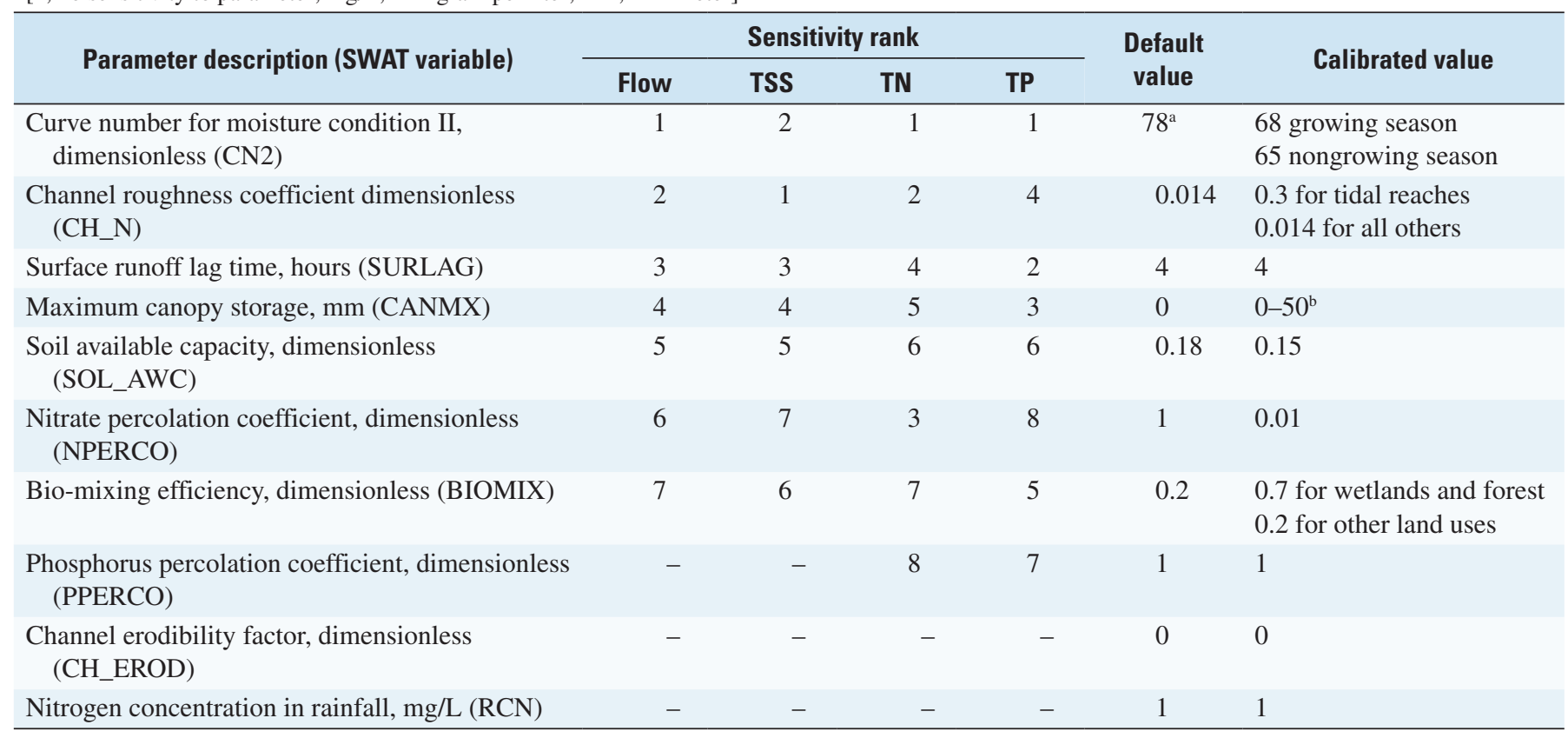

${ }^{a}$ Values are for agricultural lands with poorly draining soils.

${ }^{\mathrm{b}}$ Increasing values with increasing vegetation cover, with $50 \mathrm{~mm}$ maximum for forested areas.

\section{Tull Creek}

Because land use predominantly is agricultural, the most important considerations for Tull Creek hydrologic calibration were associated with row-crop and pasture agriculture. Curve numbers, which had the highest sensitivity rank in the sensitivity analysis, are a function of hydrologic soil group, vegetation, land use, cultivation practice, and antecedent moisture conditions. Curve numbers associated with each agricultural practice were adjusted from default parameter values to reflect various agricultural practices, such as tillage, cover crop, plant growth, and artificial drainage (table 4). The relatively low calibrated curve numbers reflect improved infiltration capacity because of artificial drainage. Other SWAT applications of artificially drained areas have been calibrated with similarly low curve numbers (Hu and others, 2007).

Overland flow is computed using a roughness coefficient, which was calibrated to reflect higher flow resistance in the vegetated lowlands. As water approaches the estuary, backflow effects are important in the slow moving waters. Other parameters that were calibrated include the canopy storage capacity and soil available water capacity.

Using the calibrated parameter values, the model reasonably simulated streamflow during the calibration period.
Simulated monthly flows were in good agreement with the observations with an $\mathrm{R}^{2}$ of 0.83 and $\mathrm{E}$ value of 0.87 (fig. 5), which were well above the calibration criteria. Watersheds to which the SWAT model was applied had similar E values. For example, an evaluation of SWAT for a coastal plain agricultural watershed in Georgia indicated a monthly $\mathrm{E}$ of 0.8 (Bosch, 2004). For the 1.6-year comparison period for the Tull Creek watershed, the relative error between modeled and simulated streamflow volume was 2.7 percent, which is below the recommended criterion of 10 percent (Lumb and others, 1994). Sources of error and uncertainty associated with Tull Creek calibration included the extent of the ditch-drainage network and the effects of tidal influence on streamflow.

\section{West Neck Creek}

Because Tull Creek watershed was well calibrated, the parameters obtained for hydrologic response units at Tull Creek were applied to the calibration of the West Neck Creek watershed with some modifications. Urban-basin parameters were adjusted for the hydrologic calibration. These adjustments included the amount of impervious area and the average connected impervious area associated with each urban land type. 

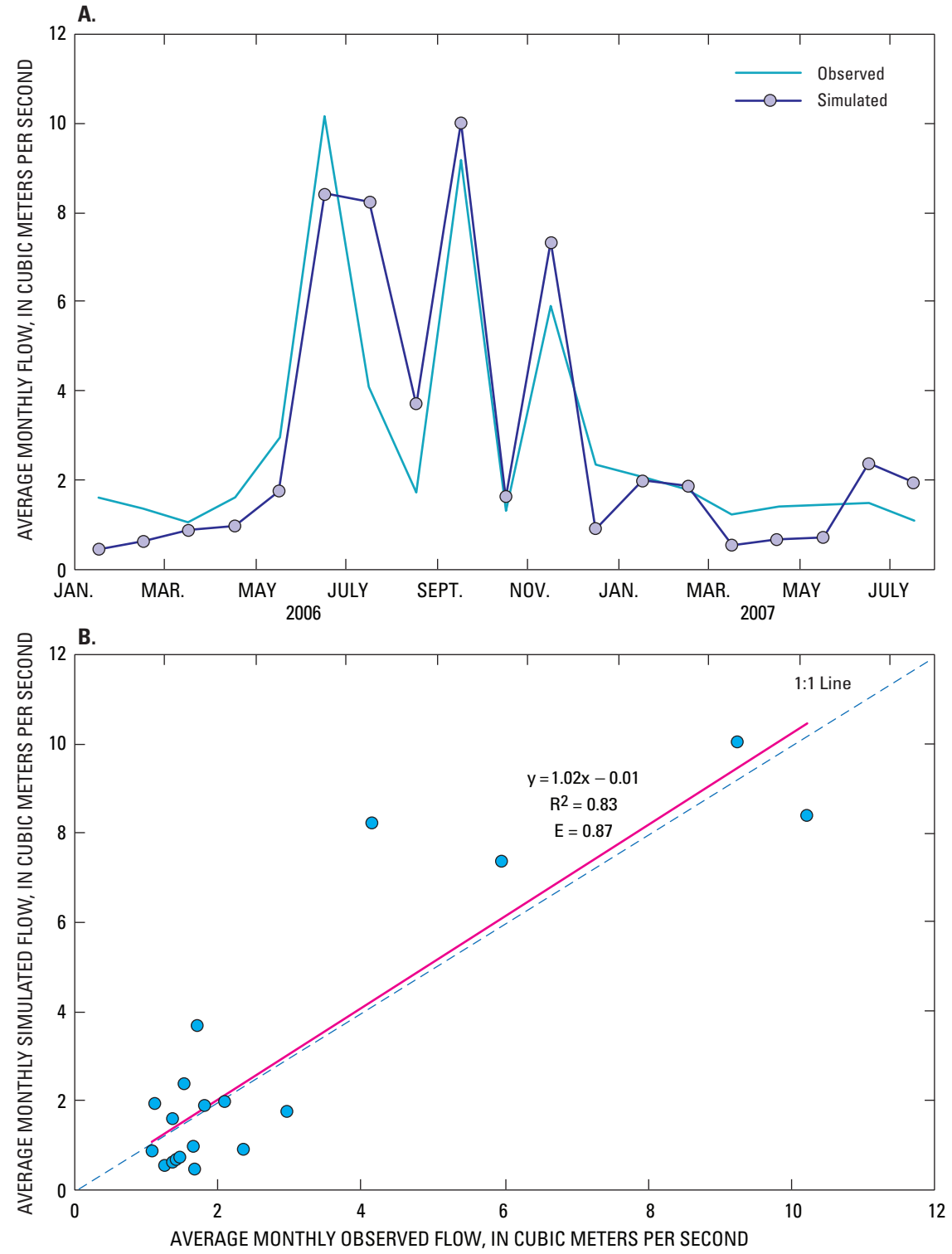

Figure 5. Model results for Tull Creek hydrology: (A) simulated and observed flows for 19-month calibration period, (B) observed and simulated mean flows and best-fit line. 
Monthly mean flow comparisons between observed flow (1.4 years) and simulated flow showed moderate agreement (fig. 6), with $\mathrm{R}^{2}=0.58$ and $\mathrm{E}=0.76$. The model predicted higher-than-observed streamflows in winter and spring months when precipitation normally is high and evapotranspiration is low.

\section{Water Quality}

After hydrology was calibrated, water-quality calibration was performed. The water-quality calibration consisted of running the watershed model, comparing water-quality time series output to available water-quality observation data, and adjusting constituent loading and in-stream water-quality parameters within reasonable ranges.

\section{Tull Creek}

A reasonable calibration of TSS concentrations for Tull Creek was obtained with small adjustment to default parameters (fig. 7). Conservation tillage was assumed for row-crop agriculture on the basis of agricultural census information (U.S. Department of Agriculture, 2002). To simulate the detaining effect of riparian areas near marshlands and wetlands, buffer strips were assumed to line streams in areas of wetland and forest land use. The regression $\mathrm{R}^{2}$ (fig. 7B) obtained was 0.19 , which is close to the calibration criterion value (0.2). The calibration was considered successful based on the time-series plot (fig. 7A), which showed that the timing and magnitude of storm-driven total suspended-solids concentrations were well simulated on June 14, 2006, and November 22, 2006. Lack of correlation was more noticeable
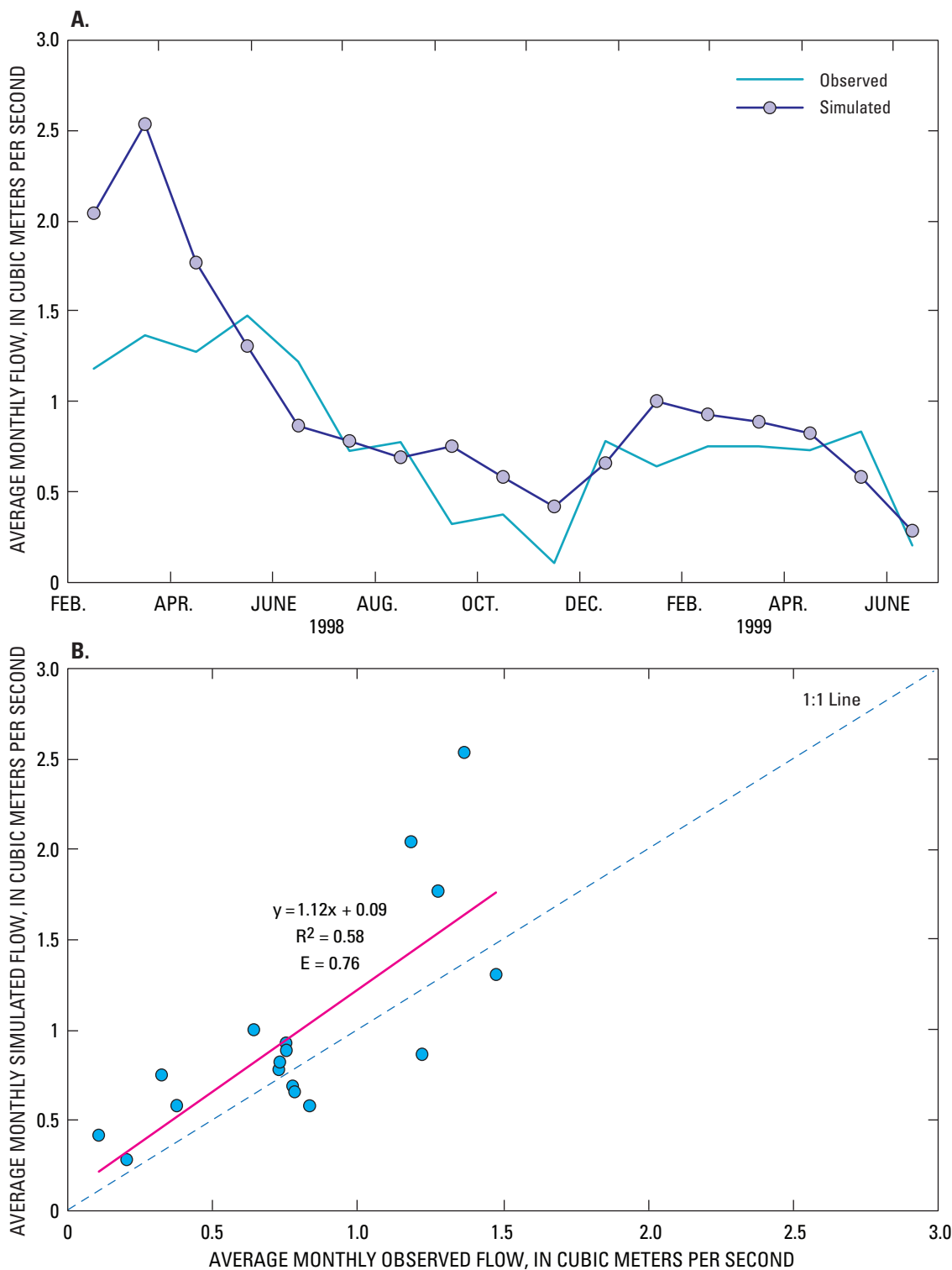

Figure 6. Model results for West Neck Creek hydrology: (A) simulated and observed flows for 17-month calibration period, (B) observed and simulated mean flows and best-fit line. 

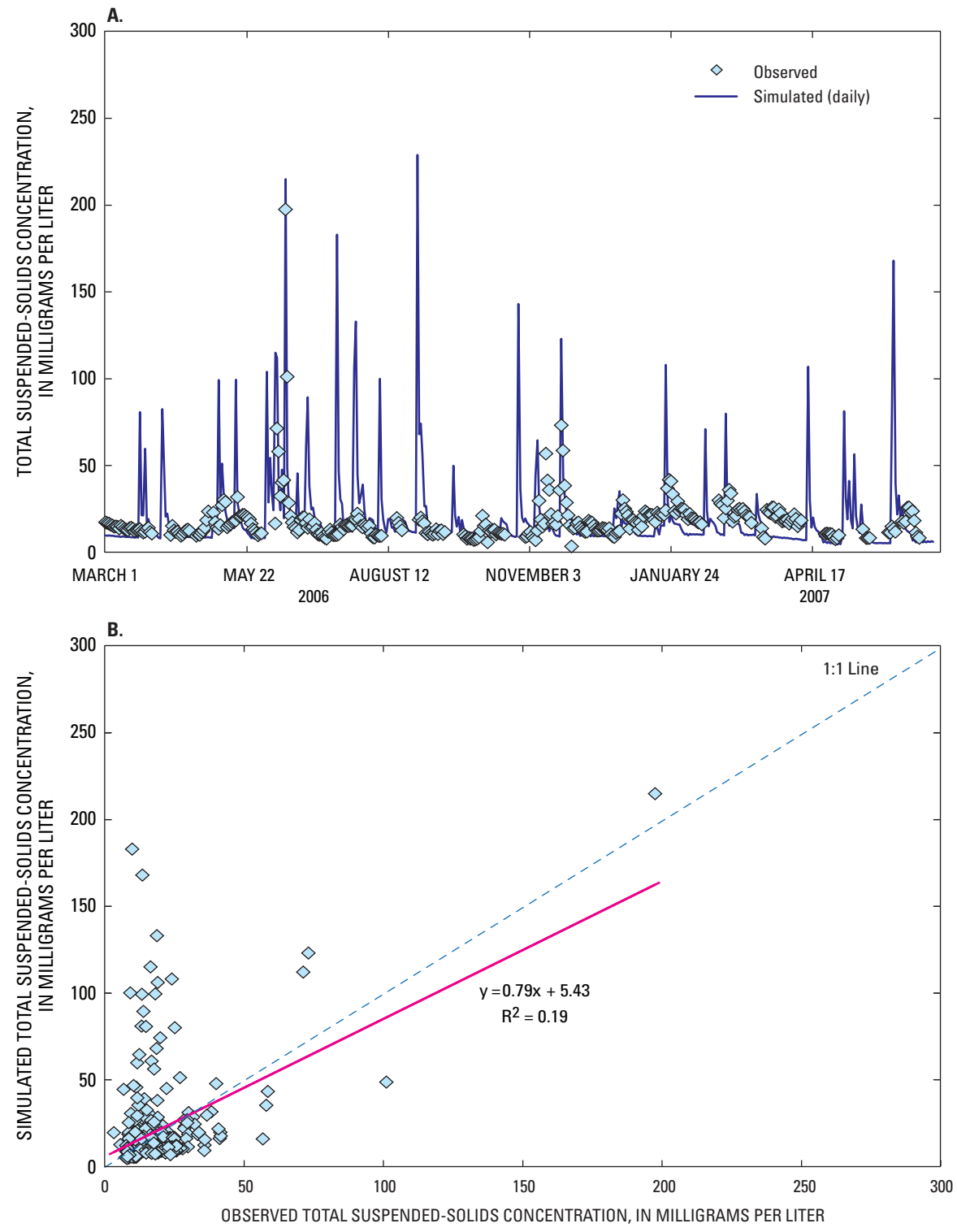

Figure 7. Model results for Tull Creek total suspended-solids calibration: (A) simulated and observed concentrations, $(B)$ regression scatter plot of daily simulated and observed concentrations and best-fit line. 
in the low range (TSS $<25 \mathrm{mg} / \mathrm{L}$ ), where turbidity readings may not have a strong correlation with TSS measurements.

The nitrogen calibration process was especially challenging because the model tended to overestimate the nitrate concentrations (fig. 8). Extensive marshlands and vegetated waterways in the watershed increase vegetative uptake and denitrification (Gilliam, 1991), which were not well represented in the model. The drainage module of SWAT allows quick flow from the soil profile, limiting the amount of time that anaerobic conditions occur and, therefore, underestimating denitrification. Some of these model limitations were compensated for by allowing denitrification at soil watercontent levels that were less than saturation.
The regression $\mathrm{R}^{2}$ obtained from the calibration was less than the calibration criterion (0.02) but increased to 0.256 when three outliers were removed. Instability in the modeling of in-stream kinetics yielded outlier nitrate and ammonia values that were not associated with high-flow events or any other change in nitrogen source. The calibration, therefore, was considered reasonable under the limitations.

The Tull Creek model was calibrated for dissolved phosphorus (also called orthophosphate) because this was the only form of phosphorus measured (fig. 9). Few model parameters were modified to calibrate phosphorus because the observed values were very low (mean $0.02 \mathrm{mg} / \mathrm{L}$ ). The main sources of phosphorus were starter fertilizer for row crops and
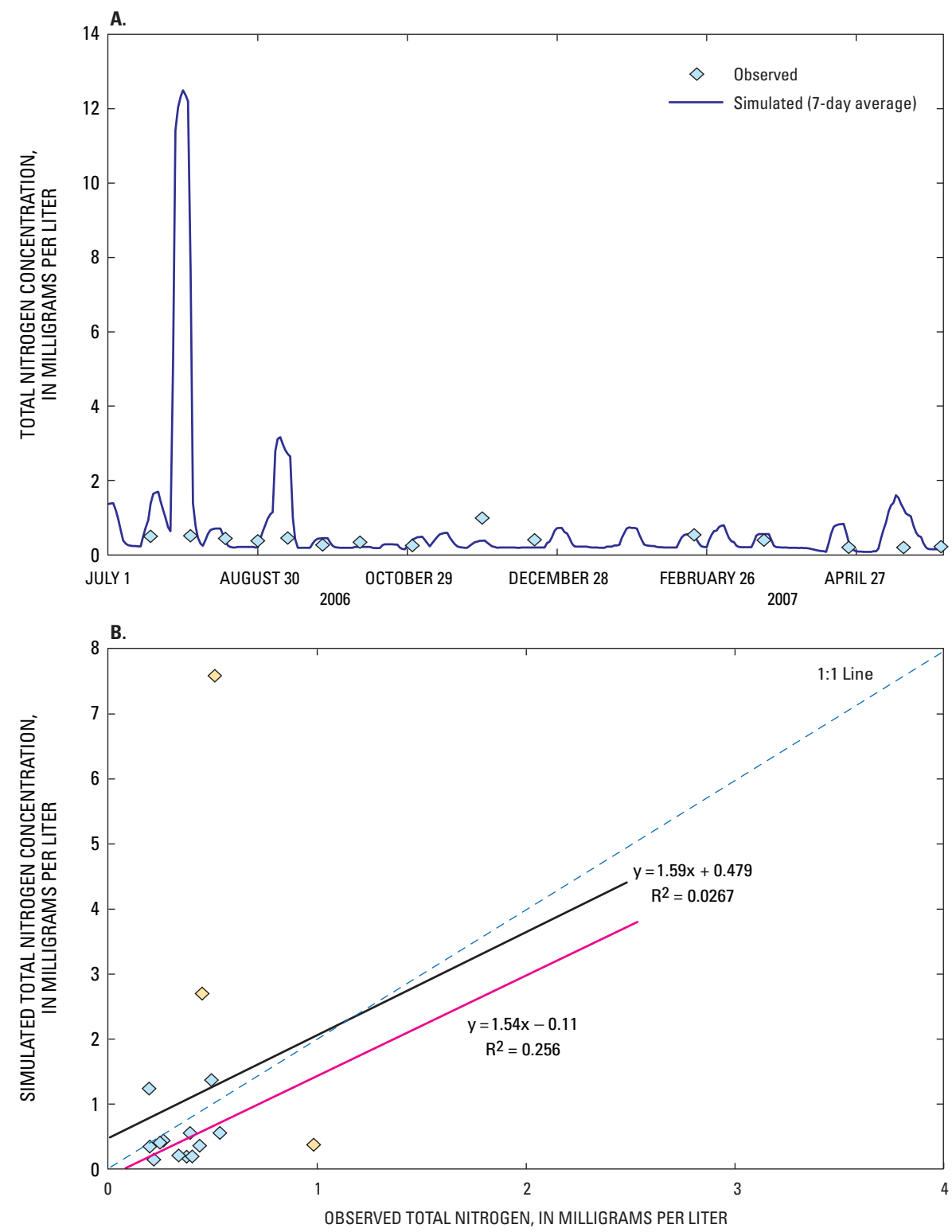

Figure 8. Model results for Tull Creek total nitrogen calibration: (A) 7-day average simulated and observed concentrations, (B) regression scatter plot and best-fit lines. The black line represents the regression for the whole data set, and the red line represents the regression excluding outliers represented in yellow. 

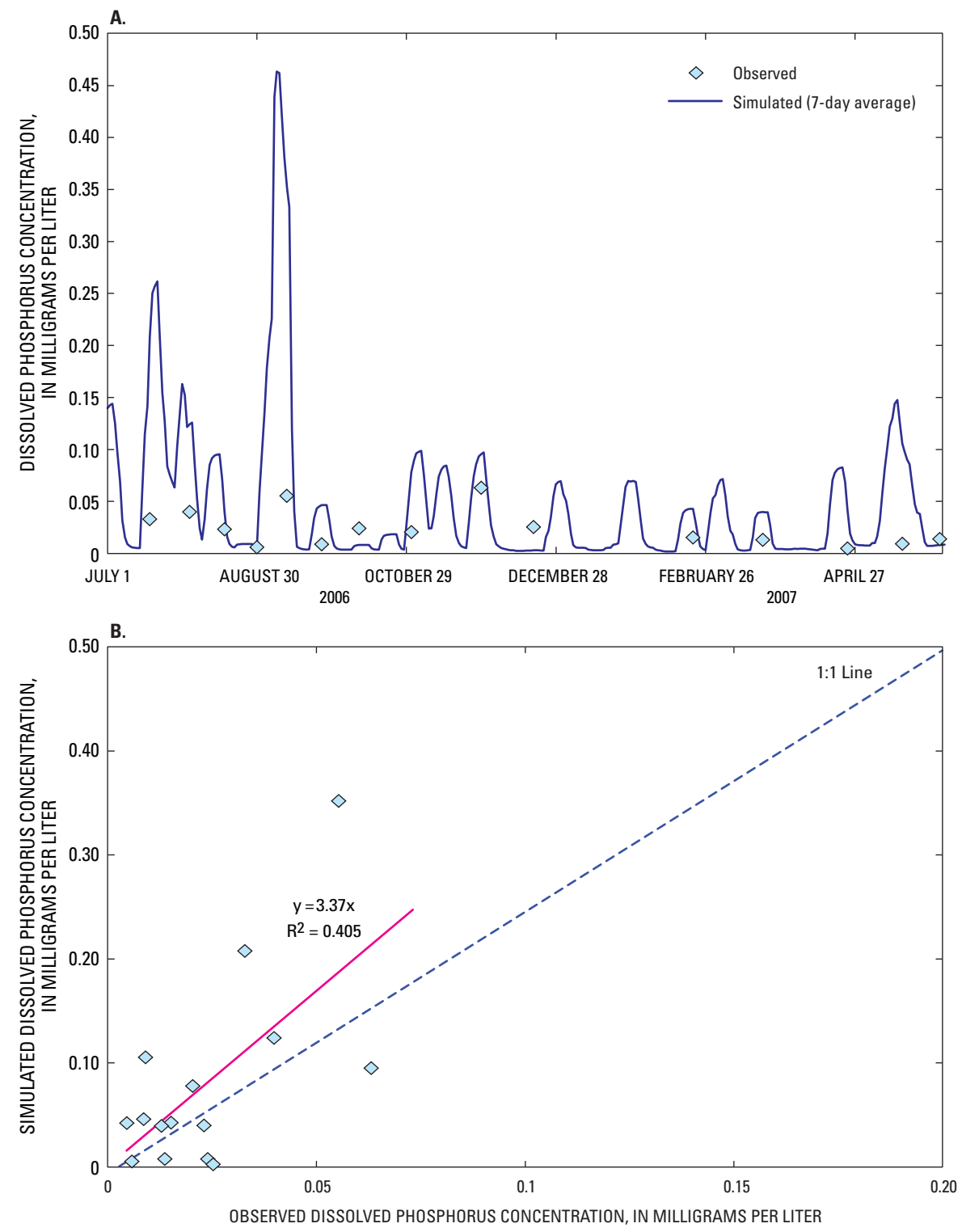

Figure 9. Model results for Tull Creek dissolved phosphorus (P) calibration: (A) 15-day average simulated and observed concentrations, (B) 15-day average simulated and observed concentrations and best-fit line. 
organic matter. Dissolved phosphorus concentrations were well calibrated $-\mathrm{R}^{2}$ of 0.405 . Previous studies have reported phosphorus $\mathrm{R}^{2}$ ranging from 0.2 to 0.8 (Gassman and others, 2007).

\section{West Neck Creek}

Total suspended-solids concentrations for West Neck Creek simulations captured some of the peak TSS concentrations and recession limbs when daily simulated values were compared to concentrations derived from turbidity readings (fig. 10). Some peaks were underestimated by the model, and an attempt was made to account for channel scour erosion, which may be enhanced by boat traffic in this bi-directional waterway; however, the simulated TSS concentrations were insensitive to the channel scour parameter.

For West Neck Creek, total nitrogen was calibrated $\left(\mathrm{R}^{2}=0.26\right)$ by suppressing the in-stream kinetics routine in SWAT and accounting for higher observed organic nitrogen concentrations (mean of $1.0 \mathrm{mg} / \mathrm{L}$; fig. 11). Urban areas contributed organic nitrogen loads, and to account for this, the organic nitrogen loads at the north inlet point were adjusted as part of the calibration process. A load of 50 kilograms per day (kg/day) was associated with the north inlet point. Other potential sources of organic nitrogen that were not accounted for could include wildlife waste, wetlands, and contributions through the shallow ground water. As in the Tull Creek watershed, observed nitrate/nitrite concentrations were low
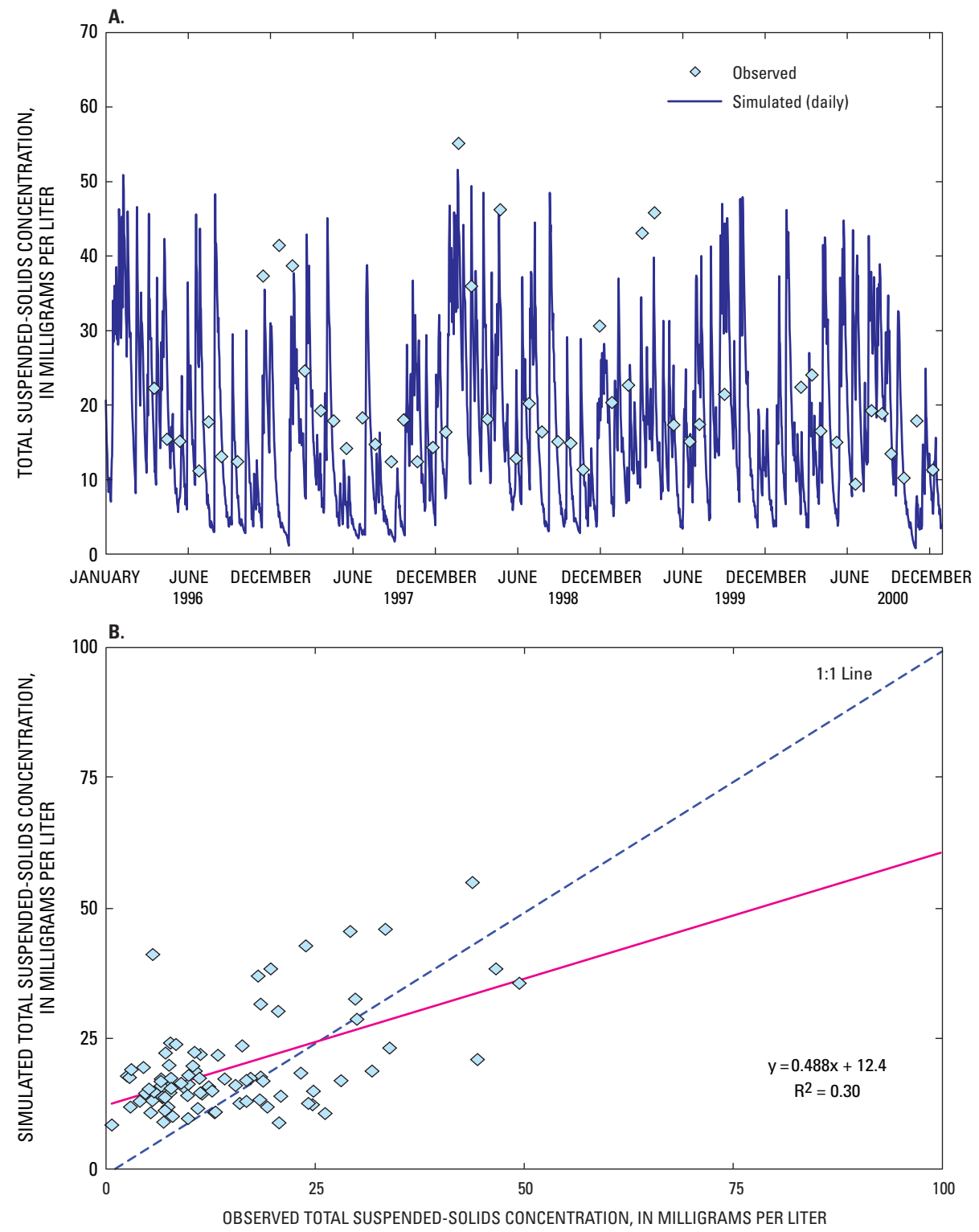

Figure 10. Model results for West Neck Creek total suspended-solids calibration: (A) daily simulated and observed concentrations, (B) daily simulated and observed concentrations and best-fit line. 

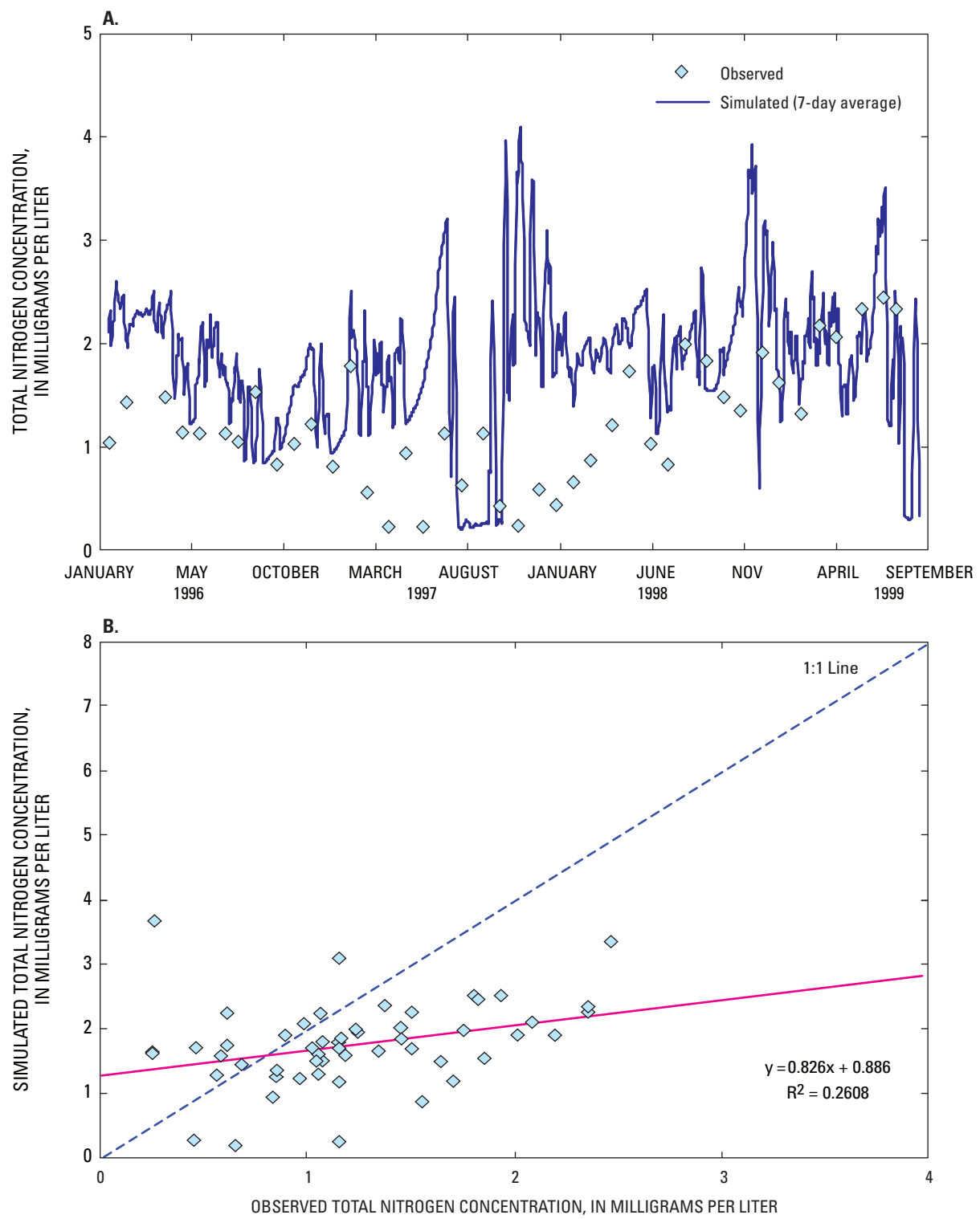

Figure 11. Model results for West Neck Creek total nitrogen (N) calibration: (A) 30-day average simulated and observed concentrations, (B) 30-day average simulated and observed concentrations and best-fit line. 
(mean of $0.14 \mathrm{mg} / \mathrm{L}$ ), and limitations associated with predicting nutrient processing in marshlands remained.

The model did not reasonably simulate dissolved phosphorus in the West Neck Creek watershed (fig. 12) based on the $\mathrm{R}^{2}$ criterion. Deficiencies in model calibration were due in part to the limited data available. Nutrient transport in urban areas is storm-driven, which is not represented in a monthly sampling scheme, and observed phosphorus concentrations were low, with average concentrations of $0.08 \mathrm{mg} / \mathrm{L}$.

\section{Model Application}

The model was considered calibrated for hydrology and for TSS and total nitrogen concentrations for both watersheds. Dissolved phosphorus concentrations were not well calibrated in the urban watershed but were successfully calibrated for the Tull Creek watershed. Accuracy of predictions can be assessed based on the $\mathrm{R}^{2}$ for calibrations. For Tull Creek, predictions for dissolved phosphorus and total suspended solids were more accurate than nitrogen predictions. For West Neck Creek, predictions for total suspended solids and total nitrogen were more accurate than the total phosphorus predictions. Verification of model accuracy was not possible due to limited data.

A calibrated data set containing parameter values for each simulated land use and constituent was developed and applied to simulate current conditions. Load estimates were prepared for the January 2006-August 2007 period and represent current conditions in these tributaries as predicted by the calibrated model. Although calibrations were performed for
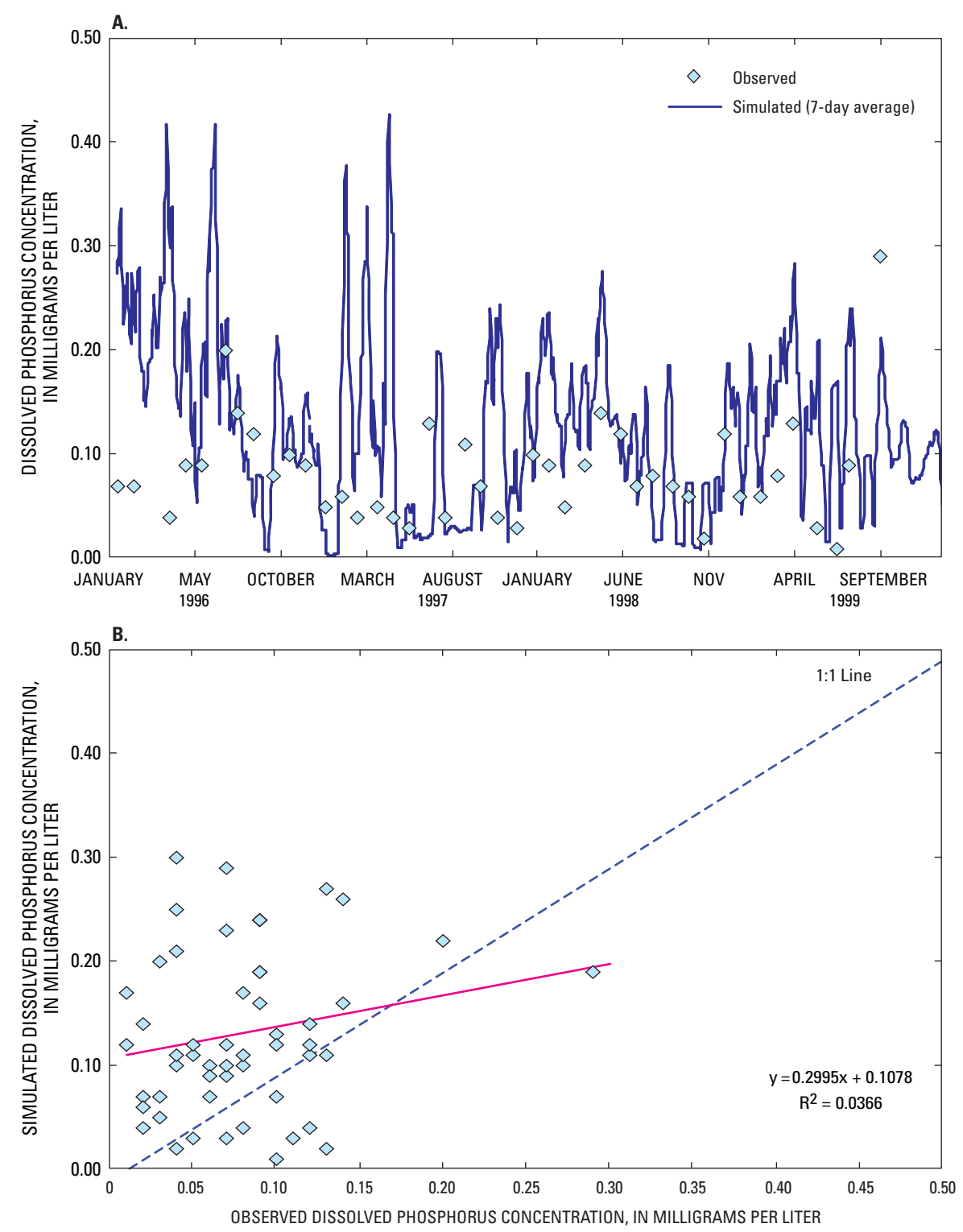

Figure 12. Model results for West Neck Creek dissolved phosphorus (P) calibration: (A) 30-day average simulated and observed concentrations, (B) 30-day average simulated and observed concentrations and best-fit line. 
the dissolved component of total phosphorus, total phosphorus was simulated for scenarios. An alternative scenario also was prepared to simulate conditions for the same period with sediment-control best-management practices.

\section{Current Conditions}

Water yield, TSS, total nitrogen, and total phosphorus concentrations yields were estimated on a daily time step and summarized by month for the Tull Creek watershed (table 5). Total suspended-solids yield closely mirrored water-yield trends, but the total nitrogen and total phosphorus yields were less related to water yield as a result of in-stream transformations and seasonal source variation.

For West Neck Creek, simulated output was summarized at the watershed outlet, which was a different location than the calibration site (table 6). Comparing the results for the same time period, total water yield was lower by 43 percent compared to Tull Creek, and the TSS export was lower (19 metric tons/ $\mathrm{km}^{2}$ ) by 48 percent. These results are expected, considering the high infiltration capacity of the dominant soils in West Neck Creek. The results also suggest that agricultural production contributes more suspended solids than urban areas in this setting. The nitrogen export from West Neck Creek was determined to be 13 percent lower than Tull Creek, which is less than the uncertainty in the calibration.

\section{Alternative Scenario}

The TSS load delivered to the Currituck Sound is of particular concern for the restoration of submerged aquatic vegetation. The analysis of Tull Creek and West Neck Creek watersheds suggests that agricultural best management practices (BMPs) that reduce sediment transport could have a beneficial effect on the water-quality management of Currituck Sound. To illustrate the potential benefit of widespread adoption of agricultural BMPs, a scenario was developed using the calibrated 2006-2007 Tull Creek model. The scenario assigned filter strips to row-crop and pasture agriculture in Tull Creek. Filter strips use closely growing vegetation, such as sod or grasses, between crop land and a stream. In this case, vegetated strips would be located along main drainage ditches. The width of the filter strip was set to $25 \mathrm{~m}$.

Table 5. Water and total suspended-solids, total nitrogen, and total phosphorus concentrations yield estimates for 2006-2007 for the Tull Creek watershed.

[mm, millimeter; $\mathrm{km}^{2}$, square kilometer; $\mathrm{kg} / \mathrm{km}^{2}$, kilogram per square kilometer]

\begin{tabular}{|c|c|c|c|c|c|}
\hline Year & Month & $\begin{array}{l}\text { Water yield } \\
(\mathrm{mm})\end{array}$ & $\begin{array}{c}\text { Total } \\
\text { suspended solids } \\
\text { (metric tons } / \mathrm{km}^{2} \text { ) }\end{array}$ & $\begin{array}{l}\text { Total nitrogen } \\
\left(\mathbf{k g} / \mathbf{k m}^{2}\right)\end{array}$ & $\begin{array}{c}\text { Total phosphorus } \\
\left(\mathbf{k g} / \mathbf{k m}^{2}\right)\end{array}$ \\
\hline \multirow[t]{12}{*}{2006} & January & 27.51 & 0.53 & 26.48 & 2.12 \\
\hline & February & 10.31 & 0.11 & 13.39 & 1.49 \\
\hline & March & 16.08 & 0.32 & 18.07 & 2.33 \\
\hline & April & 17.34 & 0.36 & 20.00 & 2.51 \\
\hline & May & 31.50 & 0.81 & 52.73 & 7.04 \\
\hline & June & 145.08 & 6.59 & 189.64 & 26.22 \\
\hline & July & 147.09 & 7.14 & 60.05 & 9.25 \\
\hline & August & 66.31 & 5.31 & 81.03 & 11.60 \\
\hline & September & 173.26 & 10.05 & 265.75 & 43.56 \\
\hline & October & 29.06 & 1.14 & 19.19 & 3.19 \\
\hline & November & 127.41 & 5.47 & 79.18 & 11.43 \\
\hline & December & 16.81 & 0.27 & 16.52 & 2.14 \\
\hline \multirow[t]{8}{*}{2007} & January & 35.90 & 0.81 & 23.97 & 2.89 \\
\hline & February & 30.62 & 0.65 & 28.69 & 3.95 \\
\hline & March & 10.35 & 0.15 & 28.39 & 4.45 \\
\hline & April & 11.93 & 0.32 & 13.76 & 1.92 \\
\hline & May & 13.51 & 0.23 & 23.63 & 3.98 \\
\hline & June & 41.70 & 1.99 & 180.97 & 37.17 \\
\hline & July & 35.15 & 1.43 & 41.61 & 5.53 \\
\hline & August & 18.21 & 0.50 & 18.03 & 2.24 \\
\hline
\end{tabular}


Table 6. Water and total suspended-solids, total nitrogen, and total phosphorus concentrations yield estimates for 2006-2007 for the West Neck Creek watershed.

\begin{tabular}{|c|c|c|c|c|c|}
\hline Year & Month & $\begin{array}{l}\text { Water yield } \\
\qquad(\mathrm{mm})\end{array}$ & $\begin{array}{c}\text { Total } \\
\text { suspended solids } \\
\text { (metric tons } / \mathrm{km}^{2} \text { ) }\end{array}$ & $\begin{array}{l}\text { Total nitrogen } \\
\left(\mathbf{k g} / \mathrm{km}^{2}\right)\end{array}$ & $\begin{array}{c}\text { Total phosphorus } \\
\left(\mathbf{k g} / \mathbf{k m}^{2}\right)\end{array}$ \\
\hline \multirow[t]{12}{*}{2006} & January & 25.93 & 0.48 & 13.98 & 1.38 \\
\hline & February & 18.41 & 0.24 & 5.57 & 0.27 \\
\hline & March & 17.42 & 0.32 & 11.68 & 1.35 \\
\hline & April & 16.00 & 0.32 & 11.62 & 1.37 \\
\hline & May & 22.19 & 0.65 & 30.51 & 3.95 \\
\hline & June & 90.38 & 4.90 & 172.15 & 25.57 \\
\hline & July & 123.35 & 6.09 & 279.87 & 46.28 \\
\hline & August & 85.99 & 5.49 & 66.00 & 10.13 \\
\hline & September & 158.90 & 7.71 & 179.68 & 30.74 \\
\hline & October & 43.19 & 1.18 & 17.54 & 2.93 \\
\hline & November & 102.89 & 4.13 & 49.25 & 11.64 \\
\hline & December & 28.44 & 0.39 & 10.98 & 0.90 \\
\hline \multirow[t]{8}{*}{2007} & January & 30.88 & 0.67 & 17.08 & 1.91 \\
\hline & February & 31.10 & 0.64 & 17.12 & 1.90 \\
\hline & March & 25.15 & 0.36 & 9.51 & 0.88 \\
\hline & April & 17.31 & 0.33 & 10.74 & 1.38 \\
\hline & May & 10.24 & 0.20 & 8.77 & 1.38 \\
\hline & June & 30.71 & 1.43 & 53.59 & 8.29 \\
\hline & July & 29.29 & 1.25 & 27.54 & 3.80 \\
\hline & August & 16.28 & 0.42 & 14.46 & 1.81 \\
\hline
\end{tabular}

The alternative scenario was simulated for the 20-month application period using the calibrated model (fig. 13). The greatest reductions occurred in November 2006, which followed fall fertilization and was a wet month. Comparing yields with the simulated existing conditions scenario, the implementation of watershed-wide filter strips lowered the TSS yield on average by 56 percent. Nutrient yields (mainly the organic forms of nitrogen and phosphorus) also were lowered, reducing total nitrogen by 45 percent and total phosphorus by 43 percent.

\section{Summary}

The SWAT model was calibrated and applied to two Coastal Plain watersheds located within the Currituck Sound basin. Calibrations were performed for hydrology, total suspended-solids, and nutrients for Tull Creek for the 2006-2007 water-quality monitoring period. Calibrations for
West Neck Creek were performed using data collected during earlier studies. The calibrated models were used to predict sediment and nutrient delivery from the watersheds and to simulate an alternative scenario in which sediment BMPs were implemented in the Tull Creek watershed.

Model calibration was limited by available water-quality and streamflow data, the tidal nature of the streams, and the human-induced hydraulic modifications present in both watersheds. Within these limitations, the model was configured to simulate monthly positive streamflows for both watersheds. Daily sediment concentrations and mean dissolved phosphorus and total nitrogen concentrations were predicted.

Nutrient yields from each watershed were low, suggesting that marshlands that buffer the streams near the outlets process much of the nutrients. The model predicted that sediment yields would be higher in the agricultural watershed than in the urban watershed. An alternative scenario that implemented a sediment BMP for agricultural lands in the Tull Creek basin lowered sediment and nutrient yield from the existing values by 29 and 54 percent, respectively. 


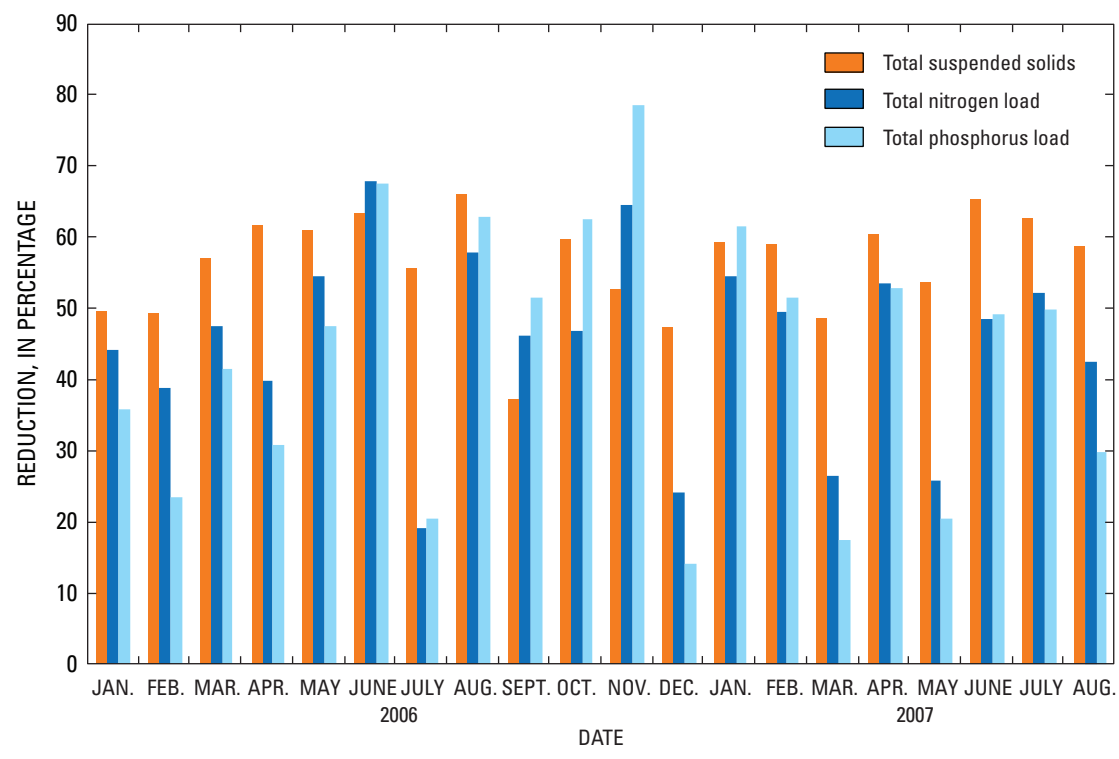

Figure 13. Average monthly percentage of reduction of total suspended solids, total nitrogen, and total phosphorus loads. Estimates are based on a 2006-2007 simulation for an alternative Tull Creek scenario with a sediment best management practice (BMP).

\section{References Cited}

Arnold, J.G., Srinivasan, R., Muttiah, R.S., and Williams, J.R., 1998, Large area hydrologic modeling and assessment, part I-Model development: Journal of American Water Resources Association, v. 34, no. 1, p. 73-89.

Bales, J.D., and Skrobialowski, S.C., 1994, Flow and salinity in West Neck Creek, Virginia, 1989-92, and salinity in North Landing River, North Carolina and Virginia, 1991-92: U.S. Geological Survey Water-Resources Investigations Report 94-4067, 36 p.

Bosch, D., 2004, Evaluation of the SWAT model on a coastal plain agricultural watershed: Transactions of the ASABE, v. 47 , no. 5 , p. $1493-1506$.

Brown, L.C., and Barnwell, T.O., Jr., 1987, The enhanced water-quality models QUAL2E and QUAL2E-UNCASDocumentation and user manual: Athens, GA, U.S. Environmental Protection Agency, EPA/600/3/87/007.

Caldwell, W.S., 2001, Hydrologic and salinity characteristics of Currituck Sound and selected tributaries in North Carolina and Virginia, 1998-99: U.S. Geological Survey WaterResources Investigations Report 01-4097, 36 p.

Evans, R.O., Bass, K.L., Burchell, R., Hinson, R.D., Johnson, R., and Doxey, M., 2007, Management alternatives to enhance water-quality and ecological function of channelized streams and drainage canals: Journal of Soil and Water Conservation, v. 67, no. 4, p. 308-320.
Fine J.M., 2008, Documentation of data collection in Currituck Sound, North Carolina and Virginia, 2006-2007: U.S. Geological Survey Open-File Report 2008-1147, 11 p.

Gassman, P.W., Reyes, M.R., Green, C.H., and Arnold, J.G., 2007, The soil and water assessment tool-Historical development, applications and future research directions: Transactions of the ASABE, v. 50, no. 4, p. 1211-1250.

Gilliam, R.W., 1991, Fertilizer nitrates not causing problems in North Carolina groundwater: Better Crops, Spring 1991, p. 6-8.

Hardy, D.H., Osmond, D.L., and Wossink, A., 2003, Soil facts-An overview of nutrient management with economic considerations: Raleigh, North Carolina Cooperative Extension Service, Publication No. AG-565-01.

Holvoet K., van Griensven, A., Seuntjens, P., and Vanrolleghem, P.A., 2005, Sensitivity analysis for hydrology and pesticide supply towards the river in SWAT: Physics and Chemistry of the Earth, v. 30, p. 518-526.

Homer, C., Huang, C., Yang, L., Wylie, B., and Coan, M., 2004, Development of a 2001 national land-cover database for the United States: Photogrammetric Engineering and Remote Sensing, v. 70, p. 829-840.

Hu, X., McIsaac, G.F., David, M.B., and Louwers, C.A.L., 2007, Modeling riverine nitrate export from an East-Central Illinois watershed using SWAT: Journal of Environmental Quality, v. 36, p. 996-1005. 
Lumb, A.M., McCammon, R.B., and Kittle, J.L., Jr., 1994, Users manual for an expert system (HSPEXP) for calibration of the Hydrological Simulation Program-Fortran: U.S. Geologic Survey, Water-Resources Investigations Report 94-4168, 102 p.

Moriasi, D.N., Arnold, J.G., Van Liew, M.W., Binger, R.L., Harmel, R.D., and Veith., T., 2007, Model evaluation guidelines for systematic quantification of accuracy in watershed simulations: Transactions of the ASABE, v. 50, no. 3, p. 885-900.

Nash, J.E., and Sutcliffe, J.V., 1970, River flow forecasting through conceptual models, part I-A discussion of principles: Journal of Hydrology, v. 10, no. 3, p. 282-290.

Natural Resources Conservation Service, 2007, Watershed boundary dataset; online at http://datagateway.nrcs.usda. gov (accessed January 10, 2007).

Natural Resources Conservation Service, 2008, Official soil series descriptions; online at http://soils.usda.gov/technical/ classification/osd/index.html (accessed February 10, 2008).

Neitsch, S.L., Arnold, J., Kiniry, G., and Williams, J.R., 2005, Soil and water assessment tool theoretical documentation, version 2005: Temple, TX, Grassland, Soil and Water Research Laboratory, Agricultural Research Service.

North Carolina Division of Emergency Management, 2002, North Carolina Floodplain Mapping-Pasquotank Basin, $20 \mathrm{ft}$ digital elevation model: Cary, NC, Floodplain Mapping Program.

Soil Conservation Service, 1986, Urban hydrology for small watersheds: U.S. Department of Agriculture, Conservation Engineering Division, Technical Release 55 [variously paged].

Southwick, R., and Norman, M.D., 2001, Impact salinity changes on fish populations in Back Bay, Virginia, 19501989, in Marshall, H.G., and Norman, M.D., eds., Proceedings of the Back Bay Ecological Symposium: Norfolk, VA, Old Dominion University, p. 138-147.
Suk, N.S., Guo, Q., and Psuty, N.P., 1998, Feasibility of using a turbidimeter to quantify suspended solids concentration in a tidal saltmarsh creek: Estuarine, Coastal and Shelf Science, v. 46, p. 383-391.

U.S. Department of Agriculture, 1995, State Soil Geographic (STATSGO) Data Base Data Use Information: Fort Worth, TX, Natural Resources Conservation Service, Miscellaneous Publication Number 1492.

U.S. Department of Agriculture, 2002, The Census of agriculture: National Agricultural Statistics Service; online at http://www.agcensus.usda.gov/Publications/2002/index.asp (accessed July 10, 2008).

U.S. Geological Survey, 2007a, Facing tomorrow's challenges-U.S. Geological Survey science in the decade 2007-2017: U.S. Geological Survey Circular 1309, 70 p.; online at http://pubs.er.usgs.gov/usgspubs/cir/cir1309 (accessed March 10, 2008).

U.S. Geological Survey, 2007b, The Cooperative Water Program-Program priorities for 2007: Water Resources Discipline Informational Memorandum No. 2007.01; online at http://water.usgs.gov/coop/priorities.html (accessed March 10, 2008).

Virginia Department of Environmental Quality, 2007, Water quality monitoring programs; online at http://www.deq. virginia.gov/watermonitoring/homepage.html (accessed June 15, 2008).

Williams, J.R., and Berndt, H.D., 1977, Sediment yield prediction based on watershed hydrology: Transactions of the ASABE, v. 20, no. 6, p. 1100-1104.

Winchell, M., Srinivasan, R., Di Luzio, M., and Arnold J., 2007, ArcSWAT interface for SWAT2005 user's guide: Temple, TX, Blackland Research Center, Texas Agricultural Experiment Station. 


\section{Prepared by:}

USGS Publishing Network

Raleigh Publishing Service Center

3916 Sunset Ridge Road

Raleigh, NC 27607

For additional information regarding this publication, contact: Ana María García, Hydrologist

USGS North Carolina Water Science Center

3916 Sunset Ridge Road

Raleigh, NC 27607

phone: 1-919-571-4000

email: agarcia@usgs.gov

Or visit the North Carolina Water Science Center Web site at: http://nc.water.usgs.gov/ 


$$
\frac{\mathbb{2}}{\mathrm{D}}
$$

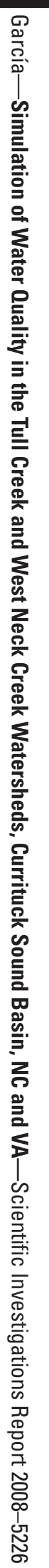

